\title{
LONG-TERM EDUCATIONAL CONSEQUENCES OF VOCATIONAL TRAINING IN COLOMBIA: IMPACTS ON YOUNG TRAINEES AND THEIR RELATIVES
}

\author{
Adriana Kugler \\ Maurice Kugler \\ Juan Saavedra \\ Luis Omar Herrera Prada \\ Working Paper 21607 \\ http://www.nber.org/papers/w21607 \\ NATIONAL BUREAU OF ECONOMIC RESEARCH \\ 1050 Massachusetts Avenue \\ Cambridge, MA 02138 \\ October 2015, Revised July 2019
}

Previously circulated as "Long-term Direct and Spillover Effects of Job Training: Experimental Evidence from Colombia." We are grateful to George Akerlof, S. Anukriti, Jacob Benus, Charles Brown, David Card, Nora Gordon, Nicole Fortin, David Greene, Bill Gormley, Rachel Heath, Harry Holzer, Caroline Hoxby, Larry Katz, Melanie Khamis, Michael Kremer, Kevin Lang, Thomas Lemieux, Ethan Ligon, Ofer Malamud, Isaac Mbiti, James Moore, David Neumark, Phil Oreopoulos, Carmen Pages, Laura Schechter, Jonathan Simonetta, Jeff Smith, Gary Solon, Jen Tobin, Shing-Yi Wang, Andy Zeitlin and seminar and conference participants at Harvard's Kennedy School, the University of British Columbia, University of Massachusetts at Amherst, George Washington University, the U.S. Bureau of the Census, the Development and America's Initiative workshops at Georgetown University, the 2016 NBER Labor Studies Spring Conference, the 2015 APPAM conference, the World Bank/IZA Employment Development Conference in Bonn, the LMK Impact Evaluation Workshop at the IDB, and the Human Development Capabilities Association Conference for helpful comments. This paper uses confidential SISBEN Census data; SABER 11 administrative data on graduation test scores from the Colombian Institute for the Promotion of Higher Education (ICFES); data from the System for Prevention and Analysis of Dropouts in Higher Education Institutions (SPADIES); and social security administrative records from the Integral System of Social Protection Information (SISPRO). The SISBEN data can be obtained directly from the Colombian Department of National Planning. The SABER 11 test scores can be obtained from ICFES. The SPADIES data can be obtained from the Colombian Ministry of Education. The SISPRO data can be obtained from the Colombian Ministry of Health and Social Protection. The authors are willing to assist in contacting these various agencies to obtain access to the data. The views expressed herein are those of the authors and do not necessarily reflect the views of the National Bureau of Economic Research.

NBER working papers are circulated for discussion and comment purposes. They have not been peer-reviewed or been subject to the review by the NBER Board of Directors that accompanies official NBER publications.

(C) 2015 by Adriana Kugler, Maurice Kugler, Juan Saavedra, and Luis Omar Herrera Prada. All rights reserved. Short sections of text, not to exceed two paragraphs, may be quoted without explicit permission provided that full credit, including $\left({ }^{\circ}\right.$ notice, is given to the source. 
Long-Term Educational Consequences of Vocational Training in Colombia: Impacts on Young Trainees and Their Relatives

Adriana Kugler, Maurice Kugler, Juan Saavedra, and Luis Omar Herrera Prada

NBER Working Paper No. 21607

October 2015, Revised July 2019

JEL No. J24,J38,J6,O17,O54

\begin{abstract}
We use administrative data and a randomization design to examine the long-term educational impacts of a large-scale vocational training program for disadvantaged youth in Colombia on trainees and their relatives. Up to eleven years after randomization, trainees were more likely to enroll in formal tertiary education, and their relatives more likely to complete secondary schooling. Various empirical tests suggest that, for females, vocational training helped relax credit constraints stemming from the direct costs of tertiary education. For males, the evidence suggests that additional tertiary education investments arise from the program improving fieldspecific knowledge and/or information about field-specific returns to tertiary education. Focusing only on labor-market outcomes and not accounting for these long-term tertiary education impacts on participants substantially understates the social desirability of the Colombian vocational training program. By contrast, including tertiary education impacts on participants increases the program's internal rate of return for women from $22.2 \%$ to $23.5 \%$ and for men from $10.2 \%$ to $20.5 \%$.
\end{abstract}

Adriana Kugler

Georgetown University

McCourt School of Public Policy

37th and O Streets NW, Suite 311

Washington, DC 20057

and NBER

ak659@georgetown.edu

Maurice Kugler

George Mason University

School of Public Policy

3351 Fairfax Drive, MS 3B1

Arlington, VA 22201

mkugler@gmu.edu
Juan Saavedra

Dornsife Center for Economic and Social Research University of Southern California

635 Downey Way

Los Angeles, CA 90089

and NBER

juansaav@usc.edu

Luis Omar Herrera Prada

International Monetary Fund

700 19th St NW

Washington, DC 20431

luis.o.herrera@me.com 


\section{Introduction}

Vocational training programs typically aim to improve the employment prospects of individuals who face difficulties entering the labor force. For instance, vocational training often targets individuals who have dropped out of the formal education system before finishing secondary school and who typically have poorer employment prospects. The goal of many training programs is, thus, to provide skills to participants to help them find employment opportunities.

The extent to which these programs are attractive social investments-particularly in developing countries - is, however, contentious. Few developing-country studies rigorously document program impacts of vocational training on labor market or other outcomes. Moreover, the few rigorously evaluated studies reach mixed conclusions. Attanasio, Kugler, and Meghir (2011) - AKM henceforth - finds that in a randomized vocational training program for disadvantaged youth implemented at scale in Colombia, earnings for women increased by close to 20 percent and formal employment participation increased for both men and women by up to seven percentage points after one year. A follow-up study finds that these early effects on labor market outcomes of the Colombian training program persist in the medium-term (Attanasio, Kugler, and Meghir 2017). AKM and Attanasio et al. (2017) find that the employment benefits of vocational training for women exceed program costs even when assuming that skills depreciate over time. However, evidence from the few other randomized controlled trials on vocational training in Argentina, the Dominican Republic, Kenya and Turkey suggest modest 
short- and long-term impacts on the labor market outcomes of participants (Alzua, Cruces, and Lopez 2016; Card et al. 2011; Hicks et al. 2014; Hirshleifer et al. 2016; Ripani et al. 2018). ${ }^{1}$

Most prior work - with one exception for the U.S. - has not examined impacts of vocational training on subsequent formal educational attainment. ${ }^{2}$ Part of the reason behind this omission in the literature could simply be due to contextual differences since training is sometimes targeted to older populations, such as displaced workers, with limited prospects for further formal education (e.g. Hirshleifer et al. 2016). However, in many settings vocational training targets youth with opportunities to attend tertiary education (e.g. Gelber, Isen, and Kessler 2016). Some studies have previously shown that skills beget skills in formal education (e.g., Heckman 2000). ${ }^{3}$ Yet, there has been no systematic examination up to now of whether participation in vocational training begets additional formal educational investments.

In this paper, we examine the effects of vocational training beyond employment and earnings outcomes of trainees. In particular, we assess the effects of a program that provided

${ }^{1}$ Alzua, Cruces, and Lopez (2016) evaluates impacts of a youth training program in Argentina that includes life skills and on-the-job training, up to four years after random assignment. The study finds stronger short-term labor market effects for men than for women, yet effects dissipate four years after random assignment. Card et al. (2011) analyze a training program in the Dominican Republic and find small positive impacts on formal employment and earnings. Hicks et al. (2014) examine the impact of an informational and training voucher intervention in Kenya and find that vouchers increased training participation, but did not increase participants' earnings. Hirshleifer et al. (2016) study the impact of a randomized training program in Turkey and find no positive effect on employment or earnings. That study does find a positive effect on employment quality one year after the program, but finds that the effect disappears three years later. Ripani et al. (2018) find small long-run employment and earnings impacts of the Dominican Republic training program.

${ }^{2}$ Gelber, Isen and Kessler (2016) examine the impacts of a summer youth employment program for teenagers in New York City on college enrollment and find that the program does not affect subsequent earnings or college enrollment of participants. A related question is explored by Carrell (2018), who assesses the extent to which community college is a pathway to a four-year degree attainment among U.S. students.

${ }^{3}$ Note that while we will examine the impact of a single intervention (i.e., vocational training) on subsequent formal education, other studies have examined complementarities of two different interventions. For example, Johnson and Jackson (2017) find evidence of dynamic complementarities in the U.S. in that the "benefits of Head Start spending were larger when followed by access to better-funded public K-12 schools, and the increases in K-12 spending were more efficacious for poor children who were exposed to higher levels of Head Start spending during their preschool years." These findings suggest that investments in the skills of disadvantaged children that are followed by sustained educational investments over time can potentially break the cycle of poverty. However, Malamud, Pop-Eleches, and Urquiola (2016) do not find evidence of complementarities between home and school enviroments in Romania. 
vocational classroom training together with a private sector apprenticeship on subsequent formal education of participants and relatives, and investigate potential mechanisms through which training may generate further educational investments. We estimate program impacts on formal educational attainment of participants in the medium- and long-term using high quality administrative educational data. We also estimate program spillovers on formal educational attainment, employment, and earnings in the medium- and long-term among relatives of program participants. To the extent that household members and families share financial and informational resources, vocational training may generate spillover benefits on relatives. No prior study has previously examined the extent to which vocational training generates educational spillover effects on relatives. Thus, here we examine the impact of a program targeted to disadvantaged youth on a broad set of outcomes (including education and labor market outcomes) and on an extensive group of individuals (including relatives). In addition, we empirically explore potential channels of the educational impacts of training.

We combine data from a randomized vocational training program for disadvantaged youth in Colombia (Youth in Action-YiA henceforth), collected by AKM, with various sources of government administrative data which allow us to track formal education and labor market trajectories of individuals and family members up to eleven years after program participation. ${ }^{4}$ We find that vocational training increases enrollment in formal tertiary education for program participants. Vocational training lottery winners are as likely as lottery losers to complete formal

\footnotetext{
${ }^{4}$ Only a few randomized trials in developing countries have had long-term follow-ups more than 10 years after random assignment. The studies with long-term follow-ups of randomized experiments are Maluccio et al. (2009), which examines the impact of childhood nutrition program in Guatemala 25 years later; Kugler and Rojas (2017), which follows CCT beneficiaries in Mexico up to 17 years later; Bettinger et al. (2018), which explores the impact of secondary school vouchers for disadvantaged youth on labor market and other outcomes up to 17 years after the lottery; Barrera-Osorio, Linden and Saavedra (forthcoming), which examines long-term educational impacts of alternative CCT payment structures in Colombia, and Baird et al. (2016), which evaluates the de-worming experiment in Kenya 10 years after random assignment.
} 
secondary school after program participation. However, training lottery winners are more likely than lottery losers to enroll in formal tertiary education between three and eleven years after training participation. Tertiary enrollment increases by 3.7 percentage points for men (base is 14.6 percent) and by 3.2 percentage points for women (base is 11.5 percent), though the gender difference is not statistically significant.

Some of the relatives of trainees also complete more formal schooling as a result of trainees' program participation. Relatives of female lottery-winner trainees are 1.7 percentage points (base is 12.4 percent) more likely to complete secondary school up to eleven years after training than relatives of male and female lottery losers. Moreover, women family members are more likely to pursue secondary schooling when they are related to either a male or female beneficiary. Also, it is women relatives who are more likely to enroll in tertiary schooling when related to a male beneficiary.

These additional downstream formal education investments among trainees and their relatives could stem from informational externalities or from improved educational inputs and resources that participants gain access to during training, which allow them to relax household credit constraints. We conduct a number of tests to try to shed light on three potential channels of this impact. First, we examine whether vocational training helps relax credit constraints in households' ability to pay the direct costs of tertiary education. Second, we examine whether trainees and their relatives learn about the value of general education through vocational training or alternatively obtain general skills through vocational training. Finally, we examine whether trainees acquire specific skills or learn about the returns to those specific skills through their training. We find evidence that for women, credit constraints were likely relaxed due to increased income for YiA trainees, and that this channel primarily accounts for the formal 
education impacts of training for them. For men, we find evidence suggesting that the formal education impacts of training primarily arise due to learning about specific skills or their returns, leading them to pursue similar fields of study in tertiary education as those in training. For relatives, we mostly find evidence for women that may be consistent with spillovers arising from gender-specific informational externalities, which may be consistent with information sharing about gender identity and attitudes within the household (e.g. Akerlof, and Kranton 2000, 2010; Bertrand, Kamenica, and Pan 2015; Fernandez, Fogli, and Olivetti 2004; Fortin 2005, 2009).

In terms of labor market outcomes, among female and male applicants, winners are 6.5 percentage points and 4 percentage points - respectively - more likely to be formally employed than losers in the long-run (base is 78.1 percent for females, 57.5 percent for males). Short-run earnings of female and male lottery winners are higher than those of lottery losers. However, the long-run daily earnings of female and male lottery winners are not significantly higher than those of lottery losers. This is not because trainees do not have higher daily earnings in the long-run, but rather due to the fact that non-trainees' earnings catch up over time. In the short-run, the program helps leapfrog trainee earnings relative to non-trainee earnings. Over time, as nontrainees spend less time in formal education and presumably gain additional labor market experience the earnings gap closes, but not completely, so that trainees are still better-off in the long-run.

To illustrate the welfare implications of the formal education impacts of vocational training, we conduct a cost-benefit analysis under two different scenarios: (i) only accounting for labor market impacts of participants accruing from vocational training participation, and (ii) accounting for increased future earnings of participants due to increased completed tertiary education. The internal rates of return (IRR) calculated on the basis of benefits from direct 
earnings effects on participants alone are 16.75 percent for the full sample, 22.1 percent for women and 10.2 percent for men. Our IRR estimate of 16.75 percent only accounting for direct labor market effects is very similar to the 16 percent IRR reported by Attanassio et al. (2017). Accounting for the tertiary education impacts of vocational training among participants yields IRRs that are 23.5 percent for women and 20.5 percent for men. Thus, not accounting for these additional downstream educational investments of trainees substantially understates the social desirability of the Colombian vocational training program, particularly among men.

In Section II, we describe the vocational training program in Colombia; prior evidence on its short-term employment effects, and related studies on the effects of vocational training for disadvantaged youth. In Section III, we describe the administrative data sources we use for the analysis and how we linked them to original program application data. In Section IV, we present results on the long-term formal education impacts on participants and relatives as well as effects on employment and earnings. In Section V, we present results of tests to disentangle the potential channels through which these impacts work. We present welfare calculations in Section VI and conclude in Section VII.

\section{Program Background and Prior Evidence}

\section{A. Program Background}

We study the long-term direct and spillover effects of Youth in Action (YiA), a largescale vocational training program introduced by the government of Colombia in the early 2000s. Between 2001 and 2005, over 130,000 disadvantaged youth residing in Colombia's largest metropolitan areas received training through $\mathrm{YiA}$. The YiA program was part of a social safety net strategy put in place by the Colombian government to support low-income families, who 
were severely affected by Colombia's 1999 recession. Targeting rules for each program ensured that participation in these three safety net programs did not overlap. ${ }^{5}$

YiA targeted socioeconomically disadvantaged youth residing in Colombia's seven largest metropolitan areas-Barranquilla, Bogotá, Bucaramanga, Cali, Cartagena, Manizales, and Medellín. ${ }^{6}$ Applicants had to be between 18 and 25 years old and they had to be out-of-school or unemployed at the time of application to be eligible to receive services.

The YiA program included two unique features. First, YiA combined a three-month classroom-training module with a three-month apprenticeship in a formal private sector job. The apprenticeship component is not a standard feature of many vocational training programs offered through schools. A second unique feature of the program was the pay-for-performance system the training institutions were subject to. Training institutions were only paid if the applicant finished the three-months of training and if they were placed in an apprenticeship after the classroom training.

In 2005, 114 legally registered, financially solvent training firms, selected in a competitive bidding process, offered 441 training courses (989 classroom sections in total). ${ }^{7}$ Trainees spent between seven and eight hours per day, five days per week, on classroom training.

\footnotetext{
${ }^{5}$ The other two programs were Families in Action and Employment in Action. Families in Action provided conditional cash transfers to poor rural households that kept their children in school and took them to receive health center check-ups. Employment in Action was a workfare program offering public employment to adults. While YiA targeted disadvantaged youth in urban areas, Families in Action targeted rural poor, displaced and indigenous populations in towns with less than 100,000 inhabitants. Employment in Action mainly targeted poor adults in rural areas and smaller cities (63 percent of participants lived in cities with less than 100,000 inhabitants). Moreover, Employment in Action operated between 2000 and 2004, before YiA program participation of the 2005 cohort, which we study in this paper.

${ }^{6}$ The exact targeting criteria included being in the socio-economic strata 1 or 2 of SISBEN, which is a national classification system used by the Colombian government to create means tests to target national welfare programs. This SISBEN targeting corresponds roughly to the lowest two deciles of the income distribution.

${ }^{7}$ The courses include a wide variety of occupations including: inventory and warehouse assistant, electrician, archival assistant, pharmacy assistant, clinical lab assistant, auto mechanic assistant, welding assistant, data entry assistant, upholstery, pre-school teacher assistant, beautician, call center assistant, agricultural machinery mechanic, seamstress, organic waste processor, flower cultivation, metal fabrication, meat processor, shoe repair services, florist, wooden machine operator, bank teller and physical rehabilitation.
} 
Classroom training combined job-specific skills with non-cognitive life skills. Trainees received a $\$ 2.20 /$ day stipend to cover for transportation and other expenses during classroom and apprenticeship modules. Female trainees with children under age seven received a higher stipend of $\$ 3.00 /$ day.

Upon completion of the classroom-training module, training firms had to place trainees in formal-sector apprenticeships. Payments to training firms were conditional on verified apprenticeship placement. This pay-for-performance element of the program created incentives for training firms to offer training that was relevant to employers' needs. In 2005, 1,009 formal sector companies offered apprenticeships to YiA participants. Trainees spent, on average, 5.19 hours per day on manufacturing, retail and trade, and service sector apprenticeships. Throughout the classroom and apprenticeship modules, trainees received self-esteem and self-advocacy mentorships through an enrichment program called Life Project (or Proyecto de Vida in Spanish).

In 2005, the government used lotteries to determine eligibility for YiA participation. For each course offered, training firms were asked to pre-select up to 50 percent more eligible applicants than the course's enrollment capacity (e.g., a course with capacity for 30 individuals would pre-select a list of up to 45 individuals). Two-thirds of applicants from these coursespecific pre-selected lists were randomly assigned to receive training. ${ }^{8}$ In $2005,33,284$ eligible youth applied for training through YiA, 19,495 of who were women. Among eligible applicants

\footnotetext{
${ }^{8}$ AKM carried out the random assignment with the help of a firm in Colombia, which conducts surveys and statistical analysis. Using a random number generator applicants were assigned to a number between 1 and the maximum number of applicants in the randomization pool in each course. Those assigned numbers between 1 and the number of spots assigned through randomization in each course were offered a place and those with a number above would be placed in a 'waiting list'. Since AKM randomized applicants in all courses, they could monitor whether someone tried to sign up for another course or eventually was accepted into the treatment group for a course. AKM also monitored changes in participation status month-by-month among those who entered the randomization pool.
} 
28,021 (84 percent) randomly received an offer to participate; women and men had similar odds of being randomized into the program.

There was close to full compliance with the randomization protocol in the 2005 training cohort. Only 0.18 percent of youth offered training turned it down and only 1.29 percent of those who were not offered training ended up receiving training through YiA. Ninety seven percent of participants completed the classroom-training module and 92 percent also completed the job apprenticeship. Moreover, YiA applicants randomly assigned to the control group did not receive other forms of publicly-funded training as no other public training program for disadvantaged youth existed in Colombia at the time. ${ }^{9}$ In our analyses, we use the original random assignment to estimate intent-to-treat (ITT) effects comparing those randomly assigned to a spot in a course and those randomly assigned to the 'waiting list' or control group in the same course.

\section{B. Prior Evidence on the Effects of YiA}

AKM show that, one year after the lottery, female training lottery winners are seven percentage points more likely to be in formal sector employment and earn 20 percent more than lottery losers. Among males, YiA increased formal employment by six percentage points but had no effect on earnings. Using the same randomization cohort as we do, Attanasio et al. (2017) document persistent earnings gains and increased likelihood of formal sector employment in the medium-term among program participants. Based on these impacts and program cost data, the study by Attanasio et al. (2017) reports an estimate of a program's internal rate of return of 16 percent which, to preview, is close to our calculations of 16.75 percent that only account for

\footnotetext{
${ }^{9}$ While the National Learning Service (Servicio Nacional de Aprendizaje, SENA) is a public entity under the Colombian Ministry of Labor, the vast majority of its course offerings provide training to currently employed workers whose employers contribute payroll taxes that finance the SENA. In fact, to register in SENA courses, one has to have a registration number provided by an employer that is included in a list of qualifying employers. SENA also provides some courses to disadvantaged populations (e.g., incarcerated populations) and those in the informal sector, but these offerings are much more limited in number and by location.
} 
direct earnings effects, as Attanasio et al. (2017) do. When downstream educational impacts are incorporated into the IRR calculations, we estimate an IRR of 22.1 percent among women and 10.2 percent among men without accounting for educational spillovers from vocational training, and 54.8 percent of our sample is female, which yields an IRR estimate of 16.75 percent for the full sample as reported above. This calculation, however, likely understates the social desirability of YiA, as it does not account either for potential impacts of training on educational attainment of trainees nor for spillovers from trainees to relatives both of which we account for in this paper.

\section{Data Sources}

\section{A. Randomization Data}

The sample for our analyses consists of a random sample of applicants from the 2005 YiA training cohort originally collected by AKM. Among all 2005 training applicants in the randomization pool, AKM collected baseline information for a sample stratified by initial treatment offer, city and gender. This baseline sample includes 2,041 applicants randomly assigned to the treatment group and 1,913 assigned to the control group. ${ }^{10}$ AKM collected baseline data in January 2005, either before the beginning of the training program or during the first week of classes to minimize any influence of participation in the program on interviewees' responses. This randomization data contain complete information on baseline characteristics for all sampled applicants.

As in AKM and Attanasio et al. (2017), baseline characteristics of training applicants in the 2005 cohort are fairly balanced across randomization groups. Table 1 reports coefficients of regressions of the variable on a treatment indicator and training institution fixed effects, to

\footnotetext{
${ }^{10}$ There were originally 4,351 individuals in the treatment and control groups of the baseline sample, but as in AKM, we drop 9.1 percent of the individuals in the sample, who were randomly assigned to the treatment and control groups after the January 18, 2005 date when all random assignments were supposed to occur. This does not introduce any bias, as we use the original random assignment for the 3,954 observations used for all our analysis.
} 
account for the randomization structure. As a result of the sample stratification by gender, 54.8 percent of lottery losers are female (even though two thirds of applicants in 2005 are female). Lottery losers are, on average, 21 years old at the time of application and 20 percent of them are married. Of lottery losers, about 24 percent have finished secondary schooling and a little over five percent have enrolled in tertiary schooling prior to the program, and these are not significantly different from those of participants in the program. Around 20 and 8.5 percent of lottery losers report being employed and employed in the formal sector at the time of application, and these employment rates are not significantly different from those of lottery winners. Average tenure before training is a little over three months. Lottery losers work, on average, 12 days per month (including zeros for those out of work) and 25 hours per week (including zeros for those out of work).

The only statistically significant difference in baseline characteristics among female lottery winners and losers is job tenure. Women lottery winners have on average slightly longer tenure in the previous job. For men, there are differences in marital status between the treatment and control groups, and age and hours worked are marginally significantly different. Male training lottery winners are, on average, less likely to be married. Importantly, complete secondary, tertiary enrollment, employment and earnings are all insignificant. These are placebo tests and, thus, make any differences in these outcomes after training more credible. For women, the characteristics of the treatment and control groups are only marginally jointly statistically different from each other at the ten percent level and for men they are jointly significant at the five percent level. The F-test of joint significance reported at the bottom of Panel A in Table 1 comes from a regression of the treatment indicator on all the characteristics included in Panel 
A. ${ }^{11}$ While the treatment and control groups are largely similar, in all the analyses that follow, we show results including the full set of characteristics in Panel A. We also conduct robustness checks that include and exclude those baseline controls that show significant differences in Panel A of Table 1.

We use applicants' full names, date of birth and adult national identification numbers to match the original randomization data to four government administrative datasets. ${ }^{12}$ This matching to administrative data enables us to obtain identifying information on relatives and to track those who registered in the program through administrative education and social security records. This means that we can follow educational and labor market outcomes of participants (and their relatives) many years after random assignment. In the 2005 applicant list, 100 percent of applicants report their full names and over 96 percent report a valid adult identification number. ${ }^{13}$ Most importantly, the first row in Panel B of Table 1 shows that there is no difference between lottery winners and losers in the probability of having a valid adult identification number. This implies that there is no prior selection in the ability to match treatment and control individuals to education and labor market data.

\section{B. Baseline Identifying Information for Relatives}

We obtain baseline information on applicants' relatives by matching the original randomization data to Colombia's 2005 census of the poor (known as 2005 SISBEN). The Colombian government uses the SISBEN census data to determine eligibility for all government subsidies. The 2005 SISBEN census covered about sixty percent of all households in Colombia

\footnotetext{
${ }^{11}$ Note that Panel A includes the measures of education from administrative records, including completed secondary and enrolled in tertiary education prior to training, as well as the administrative data on whether the applicant is working.

${ }^{12}$ The national identification number or "cédula de ciudadanía" is similar to the Social Security Number (SSN) in the U.S. This identification number allows individuals to register into all government programs and vote in Colombia.

${ }^{13}$ Valid identification numbers have at least eight digits.
} 
at the time. From the SISBEN census, we obtain identifying information for all relatives residing in the same household as YiA program applicants in 2005, which corresponds to the baseline year for the 2005 randomization cohort.

Relatives' identifiers include full names, dates of birth, national identification numbers, as well as the relationship to the applicant. The second row in Panel B of Table 1 shows that we match 87.5 percent of lottery winners and 88.1 percent of lottery losers to the 2005 SISBEN Census. These match rates are statistically indistinguishable between lottery winners and losers, indicating no differential selection in the relatives we are able to follow from the two randomization groups. While we identify relatives living in the household of the beneficiary prior to participation in the program, we can follow these relatives during and after participation in the program even after they have moved out of the households. ${ }^{14}$

Table 2 shows the characteristics of the relatives identified in the 2005 SISBEN Census. About 51 percent of relatives in the control group are female. There are seven people on average in the households of those in the control group, and about 17 percent are children of the beneficiary, 31 percent siblings, three percent spouses and 48 percent have another relationship to the beneficiary. Of those in the control group, 33 percent are younger than 15 and 79 percent are younger than 45 years of age. Only six and five percent of male and female relatives of those in the control group have completed high school and only 2.5 and 2.7 percent of male and female relatives have ever enrolled in higher education. The characteristics of relatives in the treatment and control group are mostly very similar. Household size is smaller for female participants and

\footnotetext{
${ }^{14}$ Relatives are a selected sample of those living in the household before the program starts, but they are not restricted to being in the household during and after participation in the program. This means that if there is selection of relatives, it is based on having lived in the household prior to the program. This may restrict the sample to children and young adults, who are more likely to still be going to school. However, it may also include older family members and less economically independent relatives, who may be less likely to go to school. Thus, there is no clear way in which the selection will bias the effects of the program for this sample of relatives.
} 
the fraction of female relatives is smaller, though the difference is only marginally significant. For men, household size is smaller, and they are less likely to have children of their own in the household. While both female and male relatives are similar prior to training in terms of secondary school completion and female relatives are similar in terms of tertiary school enrollment, male relatives are more likely to be enrolled in higher education prior to the training program. These pre-existing differences in relatives' education prior to training provide placebo tests. Thus, for female relatives, the placebos make more credible any results we find ex-post. For male relatives, we have to be cautious of any treatment-control difference in tertiary schooling post-training since the difference already existed pre-training.

\section{Administrative Secondary and Tertiary Education Records}

To track applicants' and relatives' educational outcomes, we use two national administrative datasets. First, we use Colombia's secondary school graduation exam (SABER 11 exam) database. The SABER 11 exam is a standardized test similar to the American SAT and is offered by the government twice a year to students in their last year of high school who are about to graduate. ${ }^{15}$ We use these data to determine whether applicants took the SABER 11 test, which we interpret as a proxy for secondary school graduation since taking the test is a graduation requirement. We match data from the exam-taking cohort of 2000 through the exam-taking cohort of 2016, eleven years after applying to YiA.

Taking the test is, therefore, the relevant outcome of interest because we code secondary school graduation as one if the applicant appears in the SABER 11 dataset and zero if not.

\footnotetext{
${ }^{15}$ The SABER 11 exam used to be named the ICFES exam, which took the acronym of the Colombian Institute for the Promotion of Higher Education (Instituto Colombiano de Fomento para la Educación Superior) that develops and offers the exam. The ICFES still administers the exam and ensures the quality of high schools and provides information to universities on students' preparation in 5 subjects (math, reading and writing in Spanish, social science, natural sciences and English).
} 
Therefore, the secondary school completion variable is well defined for the entire sample and the sample is not selected on having outcome data. We match 30 percent of those in our original sample with SABER 11 data and the differences between treatment and control groups are not significantly different from each other as shown in the second row of Panel B in Table 1. Note that this match also represents the outcome of interest, since no match indicates that the person did not take the exam and did not graduate from secondary school. As explained above, since we are also able to match applicants (and relatives) to SABER 11 data before program participation, we can conduct placebo tests examining secondary school completion outcomes before the implementation of YiA, when we should not observe any effects.

To track tertiary enrollment outcomes of applicants and relatives, we use Colombia's Education Ministry's System for Prevention and Analysis of Dropouts in Higher Education Institutions (known as SPADIES for its Spanish acronym, Sistema de Prevención y Análisis de la Deserción en Instituciones de Educación Superior). We refer to SPADIES data as the tertiary education database. The tertiary education database is an individual-level panel dataset that tracks 95 percent of tertiary education freshmen up to their degree receipt (or dropout) beginning in $1998 .{ }^{16}$ We obtained data through 2016 , eleven years after program application.

As with the secondary graduation data, appearing in the tertiary education database is the relevant outcome of interest because we code tertiary education enrollment as one if the applicant appears in the tertiary dataset and zero if not. Thus, it is not surprising that the match rate with our original sample is 18.2 and it is slightly higher for those in the treatment group as shown in the fourth row of Panel B in Table 1. The tertiary enrollment variable is well defined for the entire sample and the sample is not selected on having outcome data. We interpret

\footnotetext{
${ }^{16}$ The tertiary education database is similar to the U.S.'s National Student Clearinghouse.
} 
differences between lottery winners and losers in the probability of being matched to the tertiary education data post-randomization as a tertiary enrollment effect resulting from random assignment to YiA. As explained above, since we are also able to match applicants (and relatives) to the tertiary education dataset for some years before program participation, we can conduct placebo tests examining tertiary enrollment outcomes before the implementation of YiA, when we should not observe any effects.

\section{Social Security Records}

To track formal employment and earnings outcomes, we match applicants to Colombia's social security records collected by the Ministry of Health and Social Protection, known as SISPRO (for its Spanish acronym Sistema Integral de Información de la Protección Social). ${ }^{17}$ SISPRO is an individual-level monthly payroll tax panel dataset. It contains information on whether individuals worked in the formal sector in a given month, the number of days of formal sector employment, monthly earnings, and payroll taxes. We focus on SISPRO outcomes from 2008 to 2013 — between three and eight years after randomization. We use data only starting in 2008 since this is the year in which SISPRO began to cover the universe of formal sector workers. We focus on the following SISPRO variables: i) appearing in the SISPRO database, and ii) average daily total earnings. Note that these outcomes are well defined for the entire sample because workers not matched to the SISPRO database in a given month are not in the formal sector that month, implying that formal earnings for that month are zero. ${ }^{18}$ The last row of Panel

\footnotetext{
${ }^{17}$ The SISPRO database only includes people who worked for employers that register their workers or selfemployed workers who register themselves.

${ }^{18}$ The average daily earnings are constructed as follows. For each applicant (and relative) we first compute annual formal employment days as the sum of formal days per month (zeros included for months without formal employment) for each year 2008 through 2013. We follow the same procedure for annual formal earnings. For each applicant and relative we, then, create annual average of formal employment days and of formal earnings for the 2008-2013 period, which are our main variables of interest. Daily formal earnings are annual earnings divided by annual formal sector employment days. Throughout, we express monetary values in 2013 US dollars.
} 
$\mathrm{B}$ in Table 1 shows that match rate is 71 percent, which means that at some point during the 2008-2013 period those in our randomized sample engaged in formal employment, which is our outcome of interest. Also, the last row shows that all and female lottery winners are more likely to be matched to SISPRO, which reflects the positive impact of the program on formal employment.

One limitation of the SISPRO data is that we can only measure formal labor market outcomes, particularly employment and earnings. To estimate total earnings, we combine SISPRO data with nationally representative household survey data from Colombia's Gran Encuesta Integrada de Hogares (GEIH). For comparability with the YiA population, we restrict 2008 and $2010 \mathrm{GEIH}$ data to individuals from the lowest socio-economic strata, who would have been age-eligible at the time of YiA application and who reside in one of the seven metropolitan areas targeted by YiA. Separately for each of the 112 cells resulting from age-at-application (1825 or eight age groups), gender (male, female) and metropolitan-program-area (seven metropolitan areas) combinations, we calculate annual informal earnings and the probability of informal employment. For each YiA applicant, we then compute their annual average total earnings as the weighted average of annual formal earnings multiplied by the likelihood of formal employment for that applicant's age-gender-metropolitan area-treatment status cell and annual informal earnings multiplied by the likelihood of informal employment in the corresponding cell. Note that this imputation approach assumes the same informal sector earnings for both treated and control applicants. However, AKM find that lottery winners, particularly females, earn higher informal earnings than lottery losers in the short-term. Therefore, our imputed daily total earnings impact estimates represent a lower bound treatment effect. 


\section{Long-term Training Impacts on Education and Labor Market Outcomes}

In this section, we describe long-term training impacts on participants' and their relatives' secondary school completion, tertiary school enrollment, and on employment and earnings. In sub-section IV.A., we present results on direct effects on secondary school completion and tertiary education enrollment among vocational training participants. In subsection IV.B., we present results on indirect effects on relatives' secondary school completion and tertiary education enrollment. We, then, present results of the impacts of YiA on employment and earnings of participants and their relatives in the long-run in sub-section IV.C.

We compare all outcomes by original randomization status so that all estimates are intent-to-treat (ITT) effects. All specifications reported below in this and later sections control for the baseline characteristics in Panel A of Table 1 (observed for all applicants) including: gender, age, marital status, employment status, salary, profits, formal employment status, whether had a written contract, tenure, days worked, hours worked, whether the person completed secondary school and whether the person enrolled in tertiary education. This is important, since there were a few differences between the treatment and control groups at baseline. We also control for training institution fixed effects to account for the randomization structure, implying that we are using random variation in treatment assignment status into a course within a training institution. This is important since individuals can self-select into training institutions, but not into treatment status.

\section{A. Impacts on Participants' Secondary School Completion and Tertiary Enrollment}

Twenty five percent of male program applicants and 23.4 percent of female program applicants completed secondary school before training. There are no differences in secondary school completion rates among training lottery male and female winners and losers before 
training (Panel A of Table 1). Note that this is a compelling placebo test showing that training assignment is unrelated to pre-treatment secondary completion. Panel A in Table 3 shows that only about five and seven percent of male and female training lottery losers, respectively, complete secondary school after the lottery. Male and female lottery winners are as likely as lottery losers to complete secondary school after the lottery. Note that the average age at which individuals take the SABER 11 exam is 20.2 years of age and $38 \%$ of test-takers are 18 years or older. Participants in YiA, who are between 18 and 25 years of age, are thus well within the age range of those who take the SABER 11 exam, so older ages among participants are unlikely to be the reason why training has no effect on secondary education.

By contrast, results in Panel B of Table 3 show that training participation increases longterm enrollment in tertiary education for training participants. About fifteen percent of male lottery losers enroll in tertiary education after the training lottery. Male lottery winners are 3.7 percentage points ( 25 percent) more likely than losers to enroll in tertiary education up to eleven years after the lottery. Female lottery winners are 3.2 percentage points (28 percent) more likely to enroll in tertiary education than lottery losers eleven years after the lottery. The results are robust to the exclusion of baseline characteristics. ${ }^{19}$ On the other hand, a placebo test cannot reject the null of no pre-treatment differences between lottery winners and losers in tertiary enrollment (second to last row in Panel A of Table 1). This reinforces the causal interpretation of tertiary enrollment impact estimates. ${ }^{20}$ These results stand in contrast to evidence from a

\footnotetext{
${ }^{19}$ We carried out robustness checks leaving out all baseline characteristics, and leaving out, one at a time, the characteristics that are significantly different between lottery winners and losers for either men or women at baseline (age, marital status, job tenure and hours worked). Results from these checks, in Appendix Table A1, are of similar magnitude and significance for both males and females, suggesting that differences in baseline characteristics do not drive the results.

${ }^{20}$ In Appendix Table A2, we adjust for multiple hypotheses testing by using the Anderson adjusted False Discovery Rate (FDR) q-values. These q-values allow adjusting for the possibility of false discoveries (i.e., failing to reject null hypotheses when they are false) when hypotheses are tested for various sub-groups at once. In our context, we have
} 
randomized summer employment program for teenagers in New York City, in which participants are as likely as non-participants to enroll in college after the program (Gelber, Isen, and Kessler 2016).

\section{B. Impacts on Relatives' Secondary School Completion and Tertiary Enrollment}

In this section, we examine whether training participation indirectly affected educational outcomes of participants' relatives. If families share educational resources, training may ease household educational credit constraints due to increased participant incomes in the short-run $(\mathrm{AKM})$ and training participation may also benefit other family members' schooling. There may also be informational externalities as other family members learn about new skills or learn about returns to schooling - both general and field-specific. We return to these potential mechanisms in Section V.

Relatives of lottery winners are more likely than relatives of lottery losers to complete secondary school in the long-term. Relatives of female lottery winners are 1.7 percentage points (14 percent) more likely to complete secondary school after the training lottery, while relatives of male lottery winners as a whole do not experience any increase in secondary schooling (Columns (2) and (4), row 1 in Panel A, Table 4). ${ }^{21}$

Indirect effects on secondary school completion are bigger for female relatives than male relatives of YiA participants (Columns (2) and (4), rows 2 and 3 in Panel A of Table 4). Male relatives of male lottery winners are not more likely to complete secondary schooling after training (row 2, Column (2) in Panel A of Table 4). By contrast, row 3 of Panel A in Table 4 shows that secondary school completion rates among female relatives of male lottery winners are

6 sub-groups: male participants, female participants, male relatives of male participants, female relatives of male participants, male relatives of female participants and female relatives of female participants. The results using the FDR q-values are less precise for tertiary schooling after YiA, but show similar general results.

${ }^{21}$ Appendix Table A3 reports results excluding all baseline controls and the results are unchanged. 
2.4 percentage points (19 percent) more likely to complete secondary school. Female relatives of female lottery winners are 2.4 percentage points ( 21 percent) more likely to complete secondary school than female relatives of losers. The difference with female relatives of male lottery winners is significant at the ten percent level. Importantly, the placebo tests in Panel B of Table 2 show that secondary school completion of neither female nor male relatives of lottery winners was higher before participation in the program, giving credibility to a causal interpretation of these results. ${ }^{22}$ By contrast, male relatives of either female or male lottery winners are not more likely to complete secondary school after YiA. ${ }^{23}$

Training participation also appears to increase tertiary school enrollment of relatives of male participants, but not of those of female participants. Tertiary enrollment increases by two percentage points (22 percent) for relatives of male lottery winners compared to relatives of lottery losers (row 1, Column (4), Panel B, Table 4) and the effect is driven by female relatives (row 2, Column (6), Panel B, Table 4). Unfortunately, the placebo test for relatives of male lottery winners shows a pre-existing difference in tertiary school enrollments, which means that we cannot interpret this post-training result causally (row 4, Panel B, Table 2). On the other hand, when we separate female and male relatives, we find significant effects for female relative post-training (row 3, Panel B, Table 4) but insignificant results pre-training (row 6, Panel B, Table 2). The results show an overall effect for female relatives of 1.3 percentage points (15 percent) driven by the effect of 2.5 percentage points ( 27 percent) for female relatives of male

\footnotetext{
${ }^{22}$ We cluster standard errors by household for all specifications of household relatives' outcomes. In Appendix Table A4 we also show significance adjusted for false discovery rate accounting for 6 different subgroups. The results for female relatives of both male and female participants are significant at conventional levels with either the naïve p-value or the FDR q-value.

${ }^{23} \mathrm{We}$ also tried estimating differential effects for relatives who were older or younger than the training participants, but found no differences so we do not report them here.
} 
participants. Contrary to the finding for male relatives, the placebo for female relatives shows no pre-existing difference in Table 4.

\section{Impacts on Long-term Labor Market Outcomes of Participants and Relatives}

We examine whether the short-term effects found in AKM for labor market outcomes and in Attanasio et al. (2017) for medium-term are also evident in our data up to eight years after random assignment.

In Table 5, we replicate short-term training impact estimates on labor market outcomes using the AKM one-year survey follow-up and report them alongside the long-term effects estimated using administrative data. ${ }^{24}$ Over this period, the training effect on formal employment for males halves. One year after the lottery, male lottery winners are 7.9 percentage points (32 percent) more likely than losers to be in formal employment. Three to eight years after the lottery, they are four percentage points (5.1 percent) more likely than losers to be formally employed (Columns (2) and (4), row 1, Panel B, Table 5). These short- and long-term formal employment impact estimates for males are significantly different from each other at the five percent level. The training effect on formal employment for females is higher in magnitude for women in the long-term. One year after the lottery, female lottery winners are 6.2 percentage points (43 percent) more likely than losers to be in formal employment. Three to eight years after the lottery, female lottery winners are 6.5 percentage points $(11.3$ percent $)$ more likely than losers to be formally employed (Columns (2) and (4), row 1, Panel C of Table 5).

Earnings impact estimates among males become insignificant three to eight years out. The earnings gain estimate for male lottery winners goes from significant gains of $\$ 1.07 /$ day one year after the lottery to $\$ 0.10$ statistically insignificant three to eight years out (Columns (2) and 
(4), row 2, Panel B, Table 5). However, the short- and long-term daily earnings impact difference among males is not statistically significant (column 6). While the earnings impact of female trainees is considerably more persistent than that of males. The earnings gain estimate for female lottery winners goes from $\$ 0.60 /$ day one year after the lottery to $\$ 0.20$ /day (Columns (2) and (4), row 2 in Panel $\mathrm{C}$ of Table 5). The difference in short- and long-term daily earnings impacts among females is not statistically significant (Column (5)). ${ }^{25}$ However, even the lower earnings in the long-run represent a third of the female earnings effect in the short-run, thus showing much more persistence than for men for whom the long-run effect is only a tenth of the short-run effect. ${ }^{26}$ The differences between men and women in the long-term could be due to the fact that men are still enrolled in the formal education system, most likely at the tertiary level, while women are closer to fully realizing their educational gains in the labor market.

Overall, we interpret the smaller long-term effects on employment and earnings compared to the short-run effects, as due to the control group catching up. Comparing Columns (1) and (3) in Table 5 shows that the control group means increase over time. This catch up of un-treated individuals over time is likely due to control group individuals being less likely to be in school during that same time and accumulating experience. Thus, in the short-run, the program helps leapfrog treated individuals with respect to the control group. Then, the control group improves and closes the gap with the treated individuals.

We find no evidence of short- or long-term formal employment or earnings effects on relatives of male participants (rows 1 and 2, Columns (2) and (4), Panel B of Table 6). We do,

\footnotetext{
male and female participants are significant at conventional levels with either the naïve p-value or the FDR q-value. s (see data section for discussion). However, even with these lower bound estimates, 63 percent of the female earnings effect persists in the long-term.

${ }^{26}$ Appendix Table A5 includes the FDR q-values and shows that the results are similar when we allow for false discoveries due to multiple hypothesis testing.
} 
however, find some evidence of positive spillovers on short-term formal employment and earnings and on long-term formal employment among relatives of female participants (rows 1 and 2, Column (2) and (4), Panel $\mathrm{C}$ of Table 6). A possibility is that relatives of male participants, who appeared to get more secondary education, are still going through the formal education system, and the effects have not yet materialized in the form of better labor market outcomes. Aside from the long-term employment effect for relatives of female trainees, none of the other coefficients for the long-term effects in Table 6 are significant.

\section{Potential Channels through which Training Increases Formal Schooling}

In this section, we examine potential channels through which vocational training increases subsequent formal schooling of beneficiaries and other household members. We focus on three potential channels: the relaxation of household credit constraints for education investments; information about general returns to education investments or attainment of general education; and acquisition of actual occupation specific skills or information about occupationspecific returns.

\section{A. Credit Constraints}

Results in AKM indicate that one year after the lottery, training increased the probability of formal paid employment by 7 percentage points and earnings by 20 percent among female trainees. Among men, training had no short-term impact on earnings but had positive impacts on formal employment. Our results in the previous section show similar positive short- and longterm employment impacts of YiA for both men and women using administrative data.

Participants and their relatives may, thus, have increased educational attainment after winning the YiA lottery to the extent that stipends during training and higher earnings following training mitigated educational credit constraints. For example, some educational outlays such as 
tertiary school tuition are lumpy, and households may not have enough savings at a point in time to pay for all of them. Additional earnings resulting from training may help participants and relatives cover these fixed and sunk costs of further education acquisition. We first test for the presence of credit constraints. Then, we test whether those with higher ability (as measured by the secondary school graduation test scores) as well as those with higher earnings post-training had a higher likelihood of pursuing more formal education subsequent to vocational training.

We test for the possible presence of borrowing constraints using the strategy of Cameron and Taber (2004). We specify a Mincer equation to estimate the returns to education:

$$
\text { Earnings }_{\text {ickt }}=\varphi+\rho \text { Education }_{\text {it }}+\beta X_{\text {ickt }}+\kappa_{\mathrm{k}}+\tau_{\mathrm{t}}+\omega_{\mathrm{c}}+\varepsilon_{\text {ickt }},
$$

where the dependent variable is earnings of individual $i$, living in city $c$ working in sector $k$ in year $t$. On the right hand side, the variable Education ${ }_{\text {it }}$ captures the years of schooling; $\mathrm{X}_{\text {ickt }}$ is a vector that includes other standard variables present in a Mincerian equation (namely potential experience, marital status and gender); and $\kappa_{\mathrm{k}}, \tau_{\mathrm{t}}$, and $\omega_{\mathrm{c}}$ are fixed effects for sector, year and city.

Cameron and Taber (2004) propose to test for credit constraints by estimating the above regression using an instrumental variables (IV) approach relying on two separate variables, direct costs and indirect costs, to instrument for educational attainment. Then, this approach tests for whether the returns are higher when using direct costs as the IV than when using indirect costs as the IV. The intuition behind the Cameron and Taber (2004) approach is that in the presence of credit constraints, schooling decisions will be more sensitive to changes in the direct costs of schooling than the indirect costs, for those who are credit constrained. Credit-constrained individuals will be less responsive to a higher monetary return to schooling as they lack the liquidity to make the investment. To the extent that IV estimates using direct costs as a source of 
exogenous variation are local to credit-constrained individuals, this IV approach would produce high estimated returns to schooling. By constrast, instrumenting schooling with opportunity costs, mainly foregone income from becoming a student, should lead to smaller IV estimates of the return to schooling since indirect costs affect equally credit constrained and unconstrained individuals. As previous studies, this approach relies on stringent exclusion restrictions that require both direct and indirect costs to not affect earnings through any channel other than through years of education.

To implement the Cameron and Taber (2004) approach, we use the following as sources of variation in direct costs: commuting distance to the nearest college, whether the nearest college is private and the interaction of commuting distance and private. We estimate the commuting distance as the shortest travel distance from the person's household address at baseline to the nearest college. We do find that Colombian students in this group, like students in the U.S., tend to go to the nearest college, so that distance matters and imposes costs. Table A6 shows, among applicants who attend tertiary education, that the average distance to the college in which they enroll is less than the median distance to all available colleges. We measure these distances for each individual using geo-referencing and relying on Google maps. Distance to college and whether the nearest college is private likely satisfy the exclusion restrictions for various reasons. First, we are determining distance to college based on applicants' residential location at baseline, which is exogenous to treatment assignment. Thus, even if applicants moved to attend college as a result of treatment, distance from residential location at baseline would satisfy the exclusion restriction. Second, most students attend college in the city in which they reside and all colleges in Colombia are geographically clustered in the main metropolitan areas. Since these metropolitan areas represent well-defined local labor markets, conditional on ability, 
distance is not correlated with labor market opportunities within the metropolitan area. Third, all of the colleges that applicants in the sample attend were also established before program participation, such that the distances and whether the nearest college was private were determined before program participation.

As a source of indirect costs, we use the opportunity cost of college attendance, measured by gender-specific average wages of high school graduates in each program metropolitan areawhich corresponds to a local labor market—estimated at baseline using the 2005 Sisben census of the poor. Since the Sisben census was conducted prior to program participation, these are exante returns. High prevailing earnings in the local labor market imply high foregone earnings of college attendance. The major concern in using this variable as an instrument, as Cameron and Taber (2004) note, is that local labor market conditions at baseline are very likely correlated with local labor market conditions later, when students make college attendance decisions. ${ }^{27}$ After estimating returns to schooling coefficients using both IV specifications, we test if the estimate of $\rho$ is greater when the instrument is the direct cost rather than the indirect cost.

Table 7 presents results from this test of the existence of credit constraints. Columns (1) to (4) in Table 7 show the results for the full sample. Both instruments are relevant, as measured by the corresponding first-stage F-stat (Columns (2) and (3), Table 6). For the full sample, the results indicate that there is no significant difference between the return to scholing coefficients estimated with the direct and indirect cost instruments (Column (4), Table 6), showing no indication of credit constraints. However, when splitting the sample between men and women, the results show evidence that is consistent with women being credit-constrained. Columns (6)

\footnotetext{
${ }^{27}$ One way to circumvent this issue would be to include as an additional control current local labor market conditions in the earnings equation. However, we do not have a good measure of local labor market conditions that can be used.
} 
and (7) show that while the opportunity cost instrument is relevant for men, the first-stage for the direct cost instrument is not relevant. By constrast, Columns (10) and (11) show that both direct and indirect costs are relevant instruments for women. Moreover, the results show that the returns estimated using direct commuting costs are higher than the returns estimated using indirect costs and that this difference is significant (Column (12), Table 6). Thus, we find evidence consistent with the presence of credit constraints for college attendance for women, implying that the relaxation of credit constraints could be driving the formal education effects documented in the previous section for women participants, as well as the spillovers on relatives of women participants. Women, indeed, appear to be more credit-constrained before the program, as the baseline characteristics in Table 1 show women earning lower wages than men and having lower likelihood of having formal employment.

We then test if those more likely to respond to credit constraints are also more likely to increase formal education subsequent to training. Appendix Table A7 shows results of a model which includes the test score for secondary school graduation (as a proxy of ability) and an interaction of the YiA lottery winner dummy with the test score variable. ${ }^{28}$ If credit constraints are relaxed, those who have the abilities to enroll in tertiary education will more easily do so. ${ }^{29}$ The results show little evidence that men are more likely to enroll in tertiary education after training if they have higher scores. On the other hand, there is evidence that women with higher

\footnotetext{
${ }^{28}$ For those who did not take the exam and for whom we have no score, we impute the scores of the 25th percentile by gender. The assumption is that those who did not take the exam would have been among the lower performing students.

${ }^{29} \mathrm{~A}$ caveat to this test is that, as long as there is rationing of slots at institutions of tertiary education by academic ability, we would expect that students with higher ability would be able to enroll in tertiary education more easily even in the absence of credit constraints. However, in Colombia, most rationing of tertiary education slots by academic ability takes place in public flagship universities, for which there are no financial constraints to attendance since low-income students receive full subsidies conditional on being admitted. There is limited rationing by academic ability among a handful of very selective and expensive private institutions, which none of the applicants in our sample attend. The universities that applicants in the sample attend are largely private or public open enrollment institutions, suggesting that this test for credit constraints is indeed helpful in the Colombian context.
} 
scores do enroll more in tertiary schooling after participating in YiA. Appendix Table A8 shows results of models with interactions of the YiA indicator with an indicator of whether individuals earned above the mean two years after YiA. The results do not show much evidence that those that earned more after YiA went on to pursue tertiary education.

Credit constraints would also predict that if individuals are indeed credit constrained, any tertiary enrollment effects should concentrate on enrollment in low-cost institutions. Appendix Table A9 shows evidence that men are more likely to enroll in high-cost private universities while women are not, and the differences between men and women are marginally statistically significant. These various pieces of evidence, together with the Cameron-Taber test, point to the relevance of credit constraints to explain why training increased subsequent tertiary education for women.

\section{B. Learning about Returns to or Acquiring General Skills}

Another reason why vocational training may increase subsequent formal education is through the acquision of general information during training about the rate of return to formal education. There is evidence in other contexts (e.g. Jensen, 2010) that when students in secondary education have better information about the benefits of tertiary education, they respond by staying in school longer. Also, formal education effects of training may arise because trainees acquire general skills, which make it easier to continue studying.

In Table 8, we test directly whether the tertiary enrollment effects of participation in YiA are greater when ex-ante returns to tertiary education are higher. The variation in returns to schooling comes from estimating Mincerian wage equations of the return to a university education separately by gender and city, controlling for education, experience and a quadratic in experience. For this approach we use data from the Sisben 2005 data so that we can get ex-ante 
returns to a university education. Then, we re-estimate training impacts on tertiary education enrollment in a regression model as before, but also including ex-ante returns to a university education and the $\mathrm{YiA}$ indicator interacted with the returns to a univesity education. We do not find evidence that $\mathrm{YiA}$ drives either men or women to acquire more formal education when they live in a city with higher general returns to schooling. ${ }^{30}$ Note, however, that these results are suggestive, since in an ideal test we would be able to know if the individual knows or obtains information on these ex-ante returns.

Alternatively, it could be that YiA boosts general skills for individuals and this allows them to more easily pursue additional formal education. In particular, we explore if YiA led individuals to obtain higher test scores in the secondary school exam that would also allow them easier access to tertiary education. Table 9 shows estimates of an OLS regression of test scores on a YiA indicator. The results in Panel A show no effect of YiA on test scores for either male nor female participants. Thus, these results indicate that $\mathrm{YiA}$ is not improving general skills for either male nor female participants. Panel B shows no effects on test scores of relatives. Thus, there is also no evidence that participants or relatives are improving their general skills, as measured by test scores, as a result of YiA.

\section{Learning about Field-Specific Returns or Acquiring Field-Specific Skills}

An alternative informational externality may arise if participants learn about requirements and field-specific returns as they go through their training coursework and on-the-job apprenticeships. ${ }^{31}$ The classroom training and apprenticeships were fairly narrowly defined,

\footnotetext{
${ }^{30}$ There is only a marginally significantly negative coefficient on the interaction term for men in terms of their tertiary enrollment and a negative impact on completed secondary schooling significant at the five percent level.

${ }^{31}$ For example, Hastings, Neilson, and Zimmerman (2013) and Kirkeboen, Leuven, and Mogstad (2016) show that returns to field of study vary significantly more than returns to college quality.
} 
potentially enabling individuals to acquire field-specific knowledge. Alternatively, individuals may be learning skills specific to a field, which are useful to continue studying in that field. We find evidence consistent with this informational channel for men but not for women.

Table 10 reports transition probabilities for the full sample, for men and for women. The transition probabilities show the share of individuals who studied training courses in particular fields and went on to study a college degree in different fields. These transition probabilities suggest stickiness in fields of study. For example, the 1 in the natural science diagonal indicates that one hundred percent of those who pursued natural science training courses (e.g., clinical lab assistant, environmental assistant) and subsequently enrolled in tertiary education, did so in the fields of natural sciences and math. Thirty percent of those who followed economics and business training courses and subsequently enrolled in tertiary education, did so in economics or business-related majors. Forty percent of those who took a training course in construction (e.g., construction operator, molding and foundry worker) and subsequently enrolled in tertiary education, did so in engineering majors. Forty percent of those who trained in health and education and subsequently enrolled in tertiary education, did so in health or education majors. When transition probabilities are estimated for men and women separately, the probabilities along the diagonal are greater for men than for women, with the exception of economics and business. We find that 64 percent of men who pursued training in construction and subsequently enrolled in tertiary education, do so in engineering majors. Also, 50 percent of men who take a course in health fields and subsequently enroll in tertiary education, do so in health and education majors. Finally, 100 percent of the students who undertake YiA courses in natural sciences and subsequently enroll in natural science majors in college are men. Thus, the evidence in Table 9 shows that a high proportion of male trainees who pursue tertiary education do so in a 
field related to the field in which they trained. This is consistent with either men learning about returns to field-specific skills or acquiring these field-specific skills that allow them to continue studying in that field.

Overall, we find evidence that training increases subsequent tertiary education for women probably by the relaxation of credit constraints. By contrast, training increases tertiary education for men probably by allowing male participants to learn about specific field skills or specific returns to these skills while they train.

\section{Welfare Analysis}

To illustrate the welfare implications of the impacts of vocational training on subsequent formal education, we conduct a cost-benefit analysis under two different scenarios: i) only accounting for labor market impacts of participants accruing from vocational training participation, and ii) accounting also for increased future earnings of participants due to increased completed tertiary education. ${ }^{32}$

We estimate costs and benefits of the program and calculate internal rates of return separately for women and men. ${ }^{33}$ There are three sources of costs. The first are direct program costs. The second is the marginal cost of public funds raised through taxation. The third is the loss of job tenure associated with program participation. Direct program costs are $\$ 770$ per participant. We impute the marginal cost of public funds to be 40 cents per dollar raised through

\footnotetext{
${ }^{32} \mathrm{We}$ also tried a third scenario that accounts for increased future earnings of relatives due to increased completed secondary education and we report them below, though we are cautious because the results on relatives were present only for female relatives. We leave the tertiary school impacts out of this analysis, as there were some pre-existing trends for relatives in terms of tertiary education.

${ }^{33}$ Throughout the analysis, for each source of cost and revenue, we compute the Net Present Values (NPVs) converting into US dollars using the year-specific exchange rate (annual average) between US dollars and Colombian pesos from the Colombian Central Bank, deflating nominal costs back to real value in base year (1995) using the US-CPI change between base year and accrual of costs (or revenue) and taking the present value of the cost and revenue stream. We express the NPV in US dollars for the year of analysis (2014) using US-CPI change between the analysis and the base year.
} 
taxation (Barrios, Pycroft, and Saveyn 2013). The loss of tenure is 1.43 months, which evaluated at baseline earnings is $\$ 64$ per participant (AKM).

There are two main sources of program benefits: direct benefits to participants and educational spillovers on participants. Benefits to participants are only those from increased total earnings (formal plus informal, Table 11). We do not account for non-wage benefits of increased formal-sector employment or other potential benefits such as delayed childbearing or reduced program participation in other government programs (e.g., Bettinger et al., 2018).

To compute the NPV of direct benefits on participants, we assume a 40-year work horizon. We project annual total earnings using the annual earnings estimates from Tables 4 and 5. Specifically, we run a linear regression of annual total earnings 2006-2013 on a linear calendar-year term, separately by gender and lottery status. ${ }^{34}$ Figure 1 shows the projected earnings profiles of lottery winners and losers, separately by gender. Thin red lines describe direct earnings profiles of participants without educational spillovers. The IRRs that only account for the benefits from direct participant earnings are 22.1 percent for females and 10.2 percent for males (row 2, Panel B, Table 11). Since 54.8 percent of our sample is female, we estimate an IRR for the full sample of 16.75 percent, very similar to the 16 percent IRR reported by Attanasio et al. (2017).

To account for the additional earnings benefits of increased tertiary enrollment and retention among participants, we assume a 10 percent return to an additional year of tertiary education and multiply these gains by the gender-specific program impact on the 3-year tertiary education retention rate. We assume that the educational spillover benefits begin to accrue eight

\footnotetext{
${ }^{34} \mathrm{We}$ do not observe earnings for 2007. We estimate 2007 earnings from an interpolation of 2006 and 2008 earnings, separately by gender and lottery status.
} 
years after vocational training completion. ${ }^{35}$ Thick continuous lines in Appendix Figure A1 describe earnings profiles on participants including education spillovers. The IRRs in which benefits are direct earnings effects on participants plus additional earnings due to the impacts of vocational training on subsequent formal education are 23.5 percent for women and 20.5 percent for men (row 2, Panel B, Table 11). ${ }^{36}$

Explicitly accounting for the impact of vocational training on formal education improves the assessment of the program's net welfare benefits, particularly for men. ${ }^{37}$ For both women and men, IRRs exceed the return on Colombian sovereign bonds of 7-9 percent over the period. This analysis illustrates the welfare implications of previously undocumented impacts of vocational training on formal education, as well as possible welfare implications of household spillovers. Failing to account for these additional effects may substantially underestimate the social desirability of vocational programs like Colombia's YiA.

\footnotetext{
${ }^{35}$ The ex-ante Mincerian returns to schooling estimates from the 2005 Sisben census of the poor are between 8 and 12 percent depending on gender and metropolitan program area, so we took the (roughly) median value for these calculations. The specific formula to account for educational spillovers is a Mincerian parallel shift in which, beginning in 2014, total predicted earnings of lottery winners with the educational spillovers are equal to predicted earnings of winners without spillovers times $\left(1+\operatorname{Prob}(3 \mathrm{yr} \text { retention })^{*}(1+0.1)^{\wedge} 3\right)$. The assumption that educational spillover benefit begin to accrue only after 8 years is conservative and, if anything, would lead to understating the IRR for the case of spillovers to the extent that we do not account for possible earnings benefits from these educational spillovers in prior years after vocational school completion.

${ }^{36} \mathrm{We}$ also also estimate the benefits to non-participants as those resulting from additional secondary school completion rates among relatives of participants, but we take these results as less conclusive given pre-program differences in tertiary education for male relatives and secondary education impacts only for female relatives. We value the educational benefits on relatives using a 10 percent rate of return to an additional year education from baseline earnings of relatives, which comes from the same Mincerian equation we estimated for Tables 7 and 8 using the Sisben 2005 data. The IRRs when we account for educational relatives in addition to direct benefits and subsequent formal education of participants are 24.1 percent for women and 25.5 percent for men.

${ }^{37}$ This calculation assumes that there are no negative spillovers to non-participants, for instance, in the form of job displacement effects (e.g. Crépon et al 2013). AKM presents evidence that the program did not have differential effects in tight and weak labor markets and, thus, argue that this evidence does not show displacement for nonparticipants.
} 


\section{Conclusion}

In this paper, we analyze the long-term direct and spillover effects of a randomized vocational training program for disadvantaged youth implemented at scale in Colombia. We provide the first evidence using an experimental research design that vocational training generates subsequent formal educational investments. We find evidence that vocational training increases tertiary education of participants, and that training participation has spillover effects on secondary education of relatives of participants.

We, then, attempt to disentangle the channels through which training increases subsequent formal education. We find evidence that is consistent with the relaxation of credit constraints being the primary driver of subsequent university investments for women. On the other hand, we find that the acquisition of specific skills or information about the returns to specific skills is likely driving the increased tertiary education of men after training.

We estimate costs and benefits of the program and calculate internal rates of return separately for women and men. These calculations highlight the importance of accounting for additional human capital investments downstream as part of the benefits when conducting welfare analysis. Program IRRs in which benefits stem solely from direct earnings effects on participants are 22.1 percent for women and 10.2 percent for men. Once we account for the impact of vocational training on subsequent formal education of participants, the IRRs are 23.5 percent for women and 20.5 percent for men.

Taken together, our results indicate that a vocational training program such as Colombia's YiA that was designed to combine classroom, apprenticeships and non-cognitive skills training, and has pay-for-performance incentives built-in, is an attractive social investment and a potential avenue for social mobility. 


\section{References}

Akerlof, George A. and Rachel E. Kranton. 2000. "Economics and Identity," Quarterly Journal of Economics, 115: 715-753.

Akerlof, George A., and Rachel E. Kranton. 2010. Identity Economics: How Our Identities Affect Our Work, Wages, and Wellbeing. Princeton, NJ: Princeton University Press.

Alzua, Maria L., Guillermo Cruces and Carolina Lopez. 2016. "Long-run Effects of Youth Training Programs: Experimental Evidence from Argentina," Economic Inquiry, 54(4): 18391859.

Anderson, Michael. 2008. "Multiple Inference and Gender Differences in the Effects of Early Intervention: A Reevaluation of the Abecedarian, Perry Preschool and Early Training Project," Journal of the American Statistical Association, 103(484): 1481-1495.

Attanasio, Orazio, Adriana Kugler Costas Meghir. 2011. "Subsidizing Vocational Training for Disadvantaged Youth in Colombia: Evidence from a Randomized Trial," American Economic Journal: Applied Economics, 3 (July): 188-220.

Attanasio, Orazio, Arlen Guarín, Carlos Medina and Costas Meghir. 2017. "Vocational Training for Disadvantaged Youth in Colombia: A Long Term Follow Up," American Economic Journal: Applied Economics, 9(2): 131-143.

Baird, Sarah, Joan Hamory Hicks, Michael Kremer and Edward Miguel. 2016. "Worms at Work: Long-term Impacts of a Child Health Investment," Quarterly Journal of Economics, 131(4): $1637-1680$.

Barrera-Osorio, Felipe, Leigh Linden and Juan E. Saavedra. Forthcoming. "Medium- and Longterm Educational Consequences of Alternative Conditional Cash Transfer Designs: Experimental Evidence from Colombia," American Economic Journal: Applied Economics.

Barrios, Salvador, Jonathan Pycroft, and Bert Saveyn. 2013. "The Marginal Cost of Public Funds in the E.U.: the Case of Labor versus Green Taxes," Taxation Papers No. 35, European Commission.

Bertrand, Marianne, Emir Kamenica and Jessica Pan. 2015. "Gender Identity and Relative Income within Households," Quarterly Journal of Economics, 130(2): 571-614.

Bettinger, Eric, Michael Kremer, Maurice Kugler, Carlos Medina, Christian Posso and Juan Saavedra. 2018. "Can Educational Voucher Programs Pay for Themselves?" Unpublished manuscript.

Cameron, Stephen V. and Christopher Taber. 2004. "Estimation of Educational Borrowing Constraints Using Returns to Schooling," Journal of Political Economy, 112(1): 132-182. 
Card, David, Pablo Ibarrarán, Ferdinando Regalia, David Rosas, and Yuri Soares. 2011. "The Labor Market Impacts of Youth Training in the Dominican Republic," Journal of Labor Economics, 29(2): 267-300.

Carrell, Scott and Michael Kurlaender. 2018. "Estimating the Productivity of Community Colleges in Paving the Road to Four-Year College Success," forthcoming in Estimating the Productivity of Higher Education, NBER Press, Edited by Caroline Hoxby and Kevin Stange.

Crépon, Bruno, Esther Duflo, Marc Gurgand, Roland Rathelot and Philippe Zamora. 2013. "Do Labor Market Policies have Displacement Effects? Evidence from a Clustered Randomized Experiment," Quarterly Journal of Economics, 128(2): 531-580.

Fernandez Raquel, Alessandra Fogli and Claudia Olivetti. 2004. "Mothers and Sons: Preference Formation and Female Labor Force Dynamics," Quarterly Journal of Economics, 119(4): 12491299.

Fortin, Nicole. 2005. "Gender Role Attitudes and Women's Labour Market Outcomes across OECD Countries," Oxford Review of Economic Policy, 21: 416-438.

. 2009. “Gender Role Attitudes and Women's Labor Market Participation: Opting Out, AIDS, and the Persistent Appeal of Housewifery," Working Paper, University of British Columbia, Vancouver.

Gelber Alexander, Adam Isen and Judd Kessler. 2016. "The Effects of Youth Employment: Evidence from New York City Lotteries," Quarterly Journal of Economics, 131(1): 423-460.

Hastings Justine S., Christopher A. Neilson and Seth D. Zimmerman. 2013. "Are Some Degrees Worth More than Others? Evidence from College Admission Cutoffs in Chile," NBER Working Paper No. 19241.

Heckman, James. 2000. "Policies to Foster Human Capital," Research in Economics, 54(1): 356.

Heckman, James, and Lance Lochner. 2000. "Rethinking Education and Training Policy: Understanding the Sources of Skill formation in a Modern Economy," in Securing the Future, eds. Sheldon Danziger and Jane Waldvogel. Nueva York, NY: Russell Sage.

Hicks, Joan Hamory, Michael Kremer, Isaac Mbiti and Edward Miguel. 2014. "Vocational Education in Kenya: Evidence from a Randomized Evaluation about Youth," Unpublished manuscript.

Hirshleifer, Sarojini, David McKenzie, Rita Almeida and Cristobal Ridao-Cano. 2016. "The Impact of Vocational Training on the Unemployed: Experimental Evidence from Turkey," Economic Journal, 126(597): 2115-2146. 
Johnson, Rucker C. and C. Kirabo Jackson. 2017. "Reducing Inequality Through Dynamic Complementarity: Evidence from Head Start and Public School Spending," NBER Working Paper No. 23489.

Kirkeboen Lars, Edwin Leuven and Magne Mogstad. 2016. "Field of Study, Earnings, and SelfSelection," Quarterly Journal of Economics, 131(3): 1057-1111.

Kugler, Adriana and Ingrid Rojas. 2018. "Do CCTs Improve Employment and Earnings in the Very Long-Term? Evidence from Mexico,” NBER Working Paper No. 24248.

Malamud, Ofer, Cristian Pop-Eleches and Miguel Urquiola. 2016. "Interactions Between Family and School Environments: Evidence on Dynamic Complementarities?" NBER Working Paper No. 22112. Cambridge, MA: National Bureau of Economic Research.

Maluccio, J., J. Hoddinott, J. Behrman, R. Martorell, A. Quisumbing, A. Stein. 2009. "The Impact of Improving Nutrition During Early Childhood on Education among Guatemalan Adults," The Economic Journal, 119(537): 734-763.

Ripani, Laura, Pablo Ibarraran, Jochan Kluve and David Rosas-Schady. 2018. "Experimental Evidence on the Long Term Impacts of a Youth Training Program," Industrial and Labor Relations Review, 20(10): 1-38. 
Table 1: Baseline Characteristics of Applicants and Randomization Balance, Various Data Sources

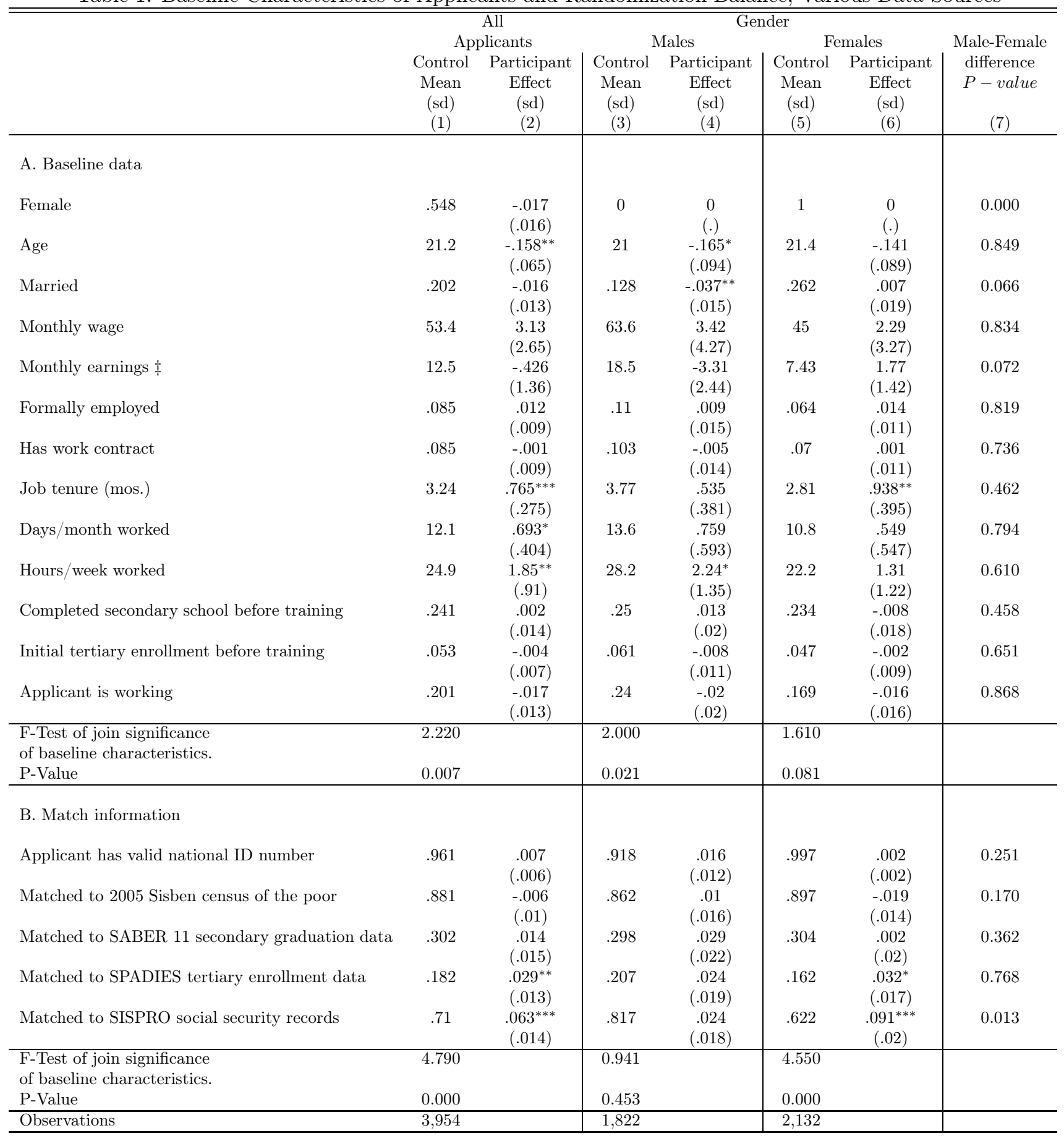

Notes: Table reports control group means and differences between participants and controls among all applicants, and separately by gender. Variables used are from: the baseline survey collected by Attanasio, Kugler and Meguir (2011) from a random sample of applicants from the 2005 training cohort; Colombia's secondary school graduation exam (SABER 11) database for secondary graduation variables and Colombia's Education Ministry's System for Prevention and Analysis of Dropouts in Higher Education (SPADIES) database for tertiary education variables; and Colombia's 2005 Census of the Poor. Participant effect estimates are from separate OLS regressions for each characteristic that also include training institution fixed effects. Wage and Earnings are expressed in 2013 USD ( 1 USD = 1869.1 Colombian Pesos). Wage, earnings, formal, contract, days and hours are zero if the applicant is out of work. Job tenure is expressed in months. Days worked are expressed per month and hours worked are expressed per week. $\ddagger$ From Self Employment ${ }^{* * *} \mathrm{p}<0.01,{ }^{* *} \mathrm{p}<0.05,{ }^{*} \mathrm{p}<0.1$ 
Table 2: Baseline Characteristics of Relatives in Applicants' Households

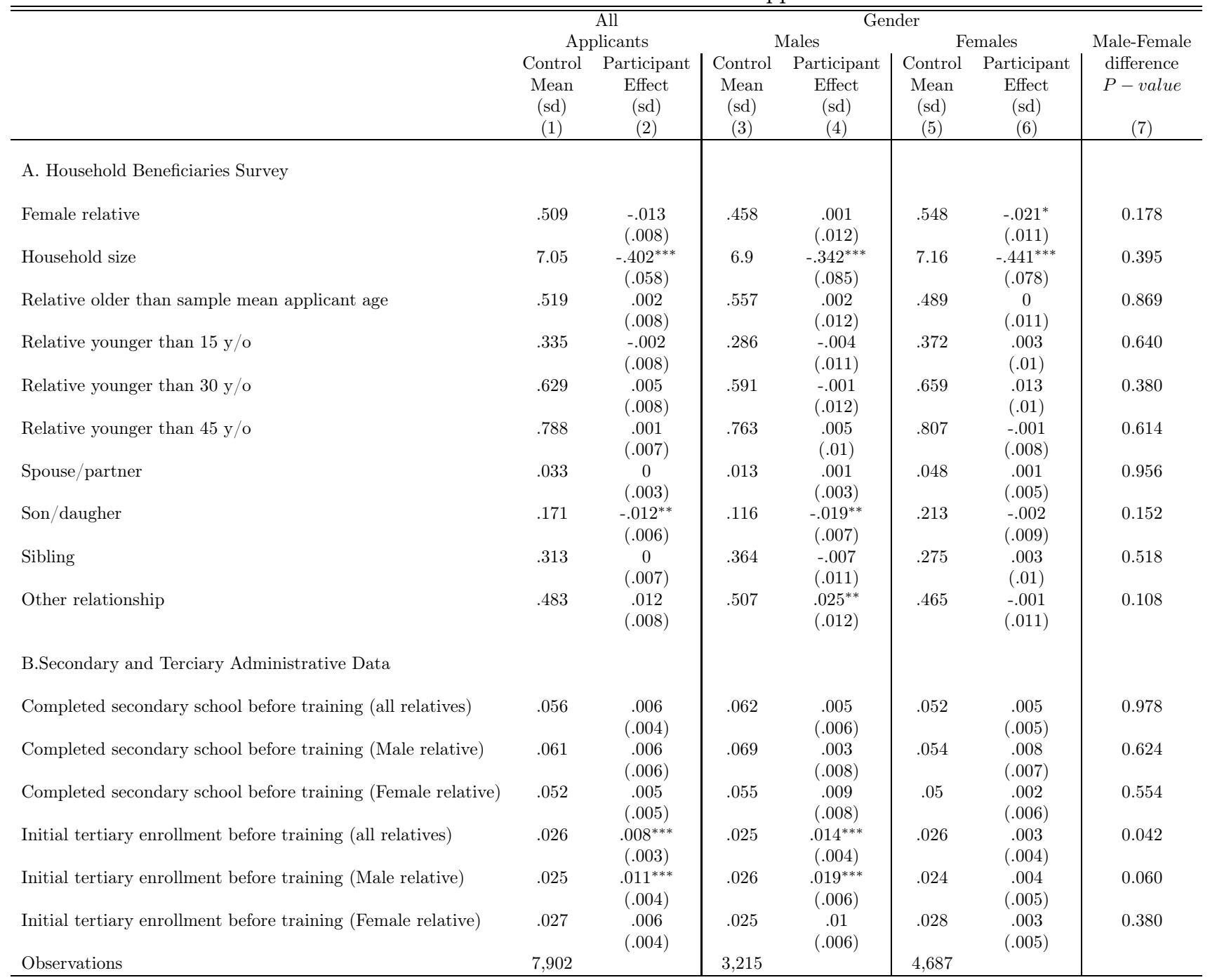

Notes: Table reports control group means and differences between participants and controls among all applicants, and separately by gender of characteristics of applicant relatives residing in the same household at baseline. In panel A data source is SISBEN 2005 census of the poor. In Panel B data sources are SABER 11 database for secondary school graduation and SPADIES database for tertiary education enrollment. Participant effect estimates are obtained from separate OLS regressions for each characteristic that also include training institution fixed effects. Wage and Earnings are expressed in 2013 USD (1 USD = 1869.1 Colombian Pesos). Wage, Earnings, Formal, Contract, Days and Hours are zero if out of work. Job tenure is expressed in months. Days worked are expressed per month and hours worked are expressed per week. $\ddagger$ From Self Employment $* * * \mathrm{p}<0.01, * * \mathrm{p}<0.05, * \mathrm{p}<0.1$ 
Table 3: Training Impacts on Applicants' Formal Education Outcomes

\begin{tabular}{|c|c|c|c|c|c|c|c|}
\hline & \multicolumn{2}{|c|}{ All Applicants } & \multicolumn{2}{|c|}{ Males } & \multicolumn{2}{|c|}{ Females } & \multirow{2}{*}{$\begin{array}{c}P-\text { value } \\
\text { Male-Female } \\
\text { difference } \\
(7) \\
\end{array}$} \\
\hline & $\begin{array}{c}\text { Control } \\
\text { Mean } \\
(1)\end{array}$ & $\begin{array}{c}\text { Participant } \\
\text { Effect } \\
(2) \\
\end{array}$ & $\begin{array}{c}\text { Control } \\
\text { Mean } \\
(3)\end{array}$ & $\begin{array}{c}\text { Participant } \\
\text { Effect } \\
(4) \\
\end{array}$ & $\begin{array}{c}\text { Control } \\
\text { Mean } \\
(5)\end{array}$ & $\begin{array}{c}\text { Participant } \\
\text { Effect } \\
(6) \\
\end{array}$ & \\
\hline \multicolumn{8}{|l|}{ A. Secondary school completion } \\
\hline Completed secondary school after training & .061 & $\begin{array}{c}.009 \\
(.008)\end{array}$ & .049 & $\begin{array}{c}.01 \\
(.011)\end{array}$ & .071 & $\begin{array}{c}.007 \\
(.012)\end{array}$ & 0.583 \\
\hline \multicolumn{8}{|l|}{ B. Initial and continued Tertiary enrollment } \\
\hline Tertiary enrollment after training & .129 & $\begin{array}{c}.031^{* * *} \\
(.011)\end{array}$ & .146 & $\begin{array}{l}.037^{* *} \\
(.018)\end{array}$ & .115 & $\begin{array}{l}.032^{* *} \\
(.015)\end{array}$ & 0.875 \\
\hline Observations & 3,953 & & 1,822 & & 2,131 & & \\
\hline
\end{tabular}

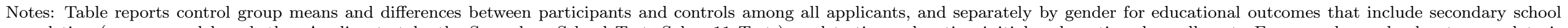

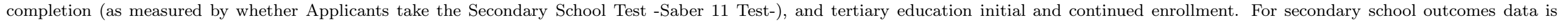

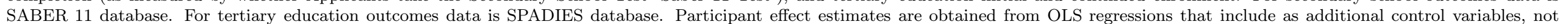

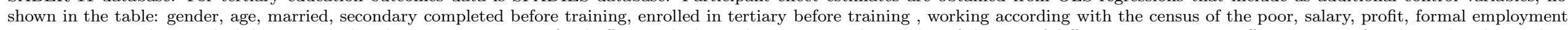

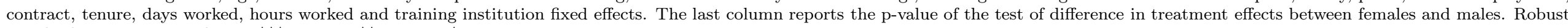
standard errors in parentheses. ${ }^{* * *} \mathrm{p}<0.01,{ }^{* *} \mathrm{p}<0.05,{ }^{*} \mathrm{p}<0.1$ 
Table 4: Impacts on Household Relatives' Formal Education Outcomes

\begin{tabular}{|c|c|c|c|c|c|c|c|}
\hline & \multicolumn{2}{|c|}{ All Applicants } & \multicolumn{2}{|c|}{ Males } & \multicolumn{2}{|c|}{ Females } & \multirow{2}{*}{$\begin{array}{c}P-\text { value } \\
\text { Male-Female } \\
\text { difference } \\
(7) \\
\end{array}$} \\
\hline & $\begin{array}{c}\text { Control } \\
\text { Mean } \\
(1) \\
\end{array}$ & $\begin{array}{c}\text { Participant } \\
\text { Effect } \\
(2)\end{array}$ & $\begin{array}{c}\text { Control } \\
\text { Mean } \\
(3) \\
\end{array}$ & $\begin{array}{c}\text { Participant } \\
\text { Effect } \\
(4)\end{array}$ & $\begin{array}{c}\text { Control } \\
\text { Mean } \\
(5) \\
\end{array}$ & $\begin{array}{c}\text { Participant } \\
\text { Effect } \\
(6) \\
\end{array}$ & \\
\hline \multicolumn{8}{|l|}{ A. Secondary school completion } \\
\hline Completed secondary school after training & .127 & $\begin{array}{l}.013^{* *} \\
(.006)\end{array}$ & .131 & $\begin{array}{c}.013 \\
(.009)\end{array}$ & .124 & $\begin{array}{l}.017^{* *} \\
(.008)\end{array}$ & 0.507 \\
\hline Completed secondary school after training (Male relative) & .134 & $\begin{array}{l}.003 \\
(.008)\end{array}$ & .133 & $\begin{array}{c}.001 \\
(.012)\end{array}$ & .136 & $\begin{array}{l}.008 \\
(.012)\end{array}$ & 0.643 \\
\hline Completed secondary school after training (Female relative) & .12 & $\begin{array}{c}.023^{* * *} \\
(.008)\end{array}$ & .128 & $\begin{array}{l}.024^{*} \\
(.013)\end{array}$ & .115 & $\begin{array}{c}.024^{* *} \\
(.01)\end{array}$ & 0.769 \\
\hline \multicolumn{8}{|l|}{ B. Initial and continued Tertiary enrollment } \\
\hline Tertiary enrollment after training & .086 & $\begin{array}{l}.01^{* *} \\
(.005)\end{array}$ & .089 & $\begin{array}{l}.02^{* *} \\
(.008)\end{array}$ & .084 & $\begin{array}{c}0 \\
(.006)\end{array}$ & 0.035 \\
\hline Tertiary enrollment after training (Male relative) & .086 & $\begin{array}{c}.005 \\
(.007)\end{array}$ & .085 & $\begin{array}{l}.014 \\
(.01)\end{array}$ & .086 & $\begin{array}{l}-.006 \\
(.009)\end{array}$ & 0.099 \\
\hline Tertiary enrollment after training (Female relative) & .087 & $\begin{array}{l}.013^{*} \\
(.007)\end{array}$ & .094 & $\begin{array}{l}.025^{* *} \\
(.012)\end{array}$ & .083 & $\begin{array}{c}.002 \\
(.009)\end{array}$ & 0.116 \\
\hline Observations & 15,733 & & 7,014 & & 8,719 & & \\
\hline
\end{tabular}

Notes: Table reports control group means for formal education outcomes of applicants' relatives in the same household at baseline and differences in educational outcomes between relatives of participants and of controls among all applicants, and separately by applicant's gender. Educational outcomes are secondary school completion (as measured by whether Applicants take the Secondary School Test -Saber 11 Test-), and tertiary education initial and continued enrollment. For secondary school outcomes data is SABER 11 database. For tertiary education outcomes data is SPADIES database. Participant effect estimates are obtained from OLS regressions that include as additional control variables, not shown in the table: applicant's gender, age, married, secondary completed before training, enrolled in tertiary before training, working according with the census of the poor, salary, profit, formal employment, contract, tenure, days worked, hours worked and training institution fixed effects. The last column reports the p-value of the test of difference in treatment effects between females and males. Robust standard errors in parentheses. ${ }^{* * *} \mathrm{p}<0.01,{ }^{* *} \mathrm{p}<0.05,{ }^{*} \mathrm{p}<0.1$. 
Table 5: Training Impacts on Applicants' Short- And Long-Term Labor Market Outcomes

\begin{tabular}{|c|c|c|c|c|c|}
\hline & \multicolumn{2}{|c|}{ Short Run } & \multicolumn{2}{|c|}{ Long Run } & \multirow{2}{*}{$\begin{array}{c}\text { Difference } \\
\left(P-\text { value }_{\chi^{2}}\right) \\
(5)\end{array}$} \\
\hline & $\begin{array}{c}\text { Control Mean } \\
\text { (1) }\end{array}$ & $\begin{array}{c}\text { Participant Effect } \\
(2)\end{array}$ & $\begin{array}{c}\text { Control Mean } \\
(3)\end{array}$ & $\begin{array}{c}\text { Participant Effect } \\
(4)\end{array}$ & \\
\hline \multicolumn{6}{|l|}{ A. Full Sample } \\
\hline Formally Employed & .188 & $\begin{array}{c}.071^{* * *} \\
(.013)\end{array}$ & .664 & $\begin{array}{c}.057^{* * *} \\
(.014)\end{array}$ & $\begin{array}{c}-.014 \\
(0.450)\end{array}$ \\
\hline Daily Earnings & 1.8 & $\begin{array}{l}.852^{* * *} \\
(.142)\end{array}$ & 8.97 & $\begin{array}{l}.218^{* *} \\
(.092)\end{array}$ & $\begin{array}{c}-.634^{* * *} \\
(0.000)\end{array}$ \\
\hline Observations & 3,799 & & 3,799 & & \\
\hline \multicolumn{6}{|l|}{ B. Male } \\
\hline Formally Employed & .245 & $\begin{array}{c}.078^{* * *} \\
(.023)\end{array}$ & .781 & $\begin{array}{c}.045^{* *} \\
(.02)\end{array}$ & $\begin{array}{c}-.033 \\
(0.211)\end{array}$ \\
\hline Daily Earnings & 2.35 & $\begin{array}{c}1.13^{* * *} \\
(.252)\end{array}$ & 10.6 & $\begin{array}{l}.195 \\
(.143)\end{array}$ & $\begin{array}{c}-.935^{* * *} \\
(0.000)\end{array}$ \\
\hline Observations & 1,682 & & 1,682 & & \\
\hline \multicolumn{6}{|l|}{ C. Female } \\
\hline Formally Employed & .145 & $\begin{array}{l}.064^{* * *} \\
(.017)\end{array}$ & .575 & $\begin{array}{l}.07^{* * *} \\
(.021)\end{array}$ & $\begin{array}{c}.006 \\
(0.797)\end{array}$ \\
\hline Daily Earnings & 1.37 & $\begin{array}{l}.658^{* * *} \\
(.168)\end{array}$ & 7.71 & $\begin{array}{l}.264^{* *} \\
(.123)\end{array}$ & $\begin{array}{l}-.394^{* *} \\
(0.026)\end{array}$ \\
\hline Observations & 2,117 & & 2,117 & & \\
\hline
\end{tabular}

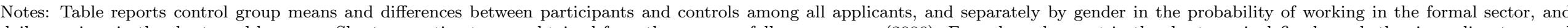

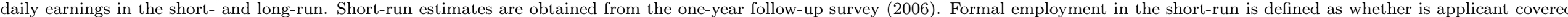

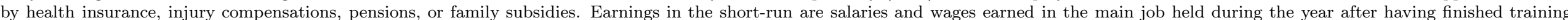

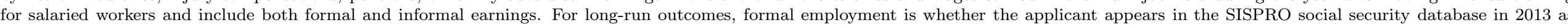

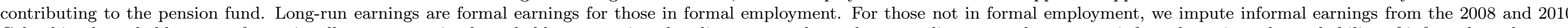

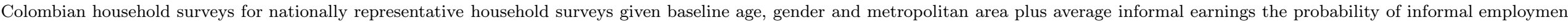

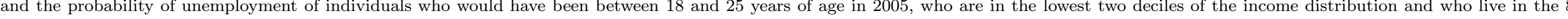

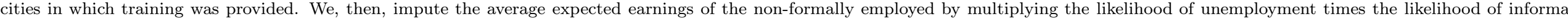

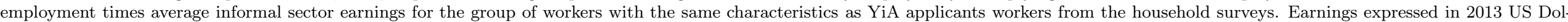

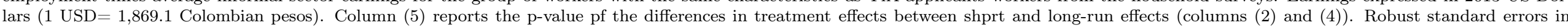
parentheses. ${ }^{* * *} \mathrm{p}<0.01,{ }^{* *} \mathrm{p}<0.05,{ }^{*} \mathrm{p}<0.1$. 
Table 6: Impacts on Household Relatives' Short- And Long-Term Labor Market Outcomes

\begin{tabular}{|c|c|c|c|c|c|}
\hline & \multicolumn{2}{|c|}{ Short Run } & \multicolumn{2}{|c|}{ Long Run } & \multirow{2}{*}{$\begin{array}{c}\text { Difference } \\
\left(P-\text { value }_{\chi^{2}}\right) \\
(5)\end{array}$} \\
\hline & $\begin{array}{c}\text { Control Mean } \\
(1)\end{array}$ & $\begin{array}{c}\text { Participant Effect } \\
(2)\end{array}$ & $\begin{array}{c}\text { Control Mean } \\
(3) \\
\end{array}$ & $\begin{array}{c}\text { Participant Effect } \\
(4)\end{array}$ & \\
\hline \multicolumn{6}{|l|}{ A. Full Sample } \\
\hline Formally Employed & .218 & $\begin{array}{l}.004^{*} \\
(.002)\end{array}$ & .252 & $\begin{array}{c}.014 \\
(.009)\end{array}$ & $\begin{array}{c}.01 \\
(0.259)\end{array}$ \\
\hline Daily Earnings & 1.02 & $\begin{array}{l}.035 \\
(.031)\end{array}$ & 8.87 & $\begin{array}{l}.034 \\
(.094)\end{array}$ & $\begin{array}{l}-.001 \\
(0.991)\end{array}$ \\
\hline Observations & 10,184 & & 10,184 & & \\
\hline \multicolumn{6}{|l|}{ B. Male } \\
\hline Formally Employed & .265 & $\begin{array}{l}-.001 \\
(.003)\end{array}$ & .236 & $\begin{array}{l}-.001 \\
(.013)\end{array}$ & $\begin{array}{c}0 \\
(0.960)\end{array}$ \\
\hline Daily Earnings & 1.29 & $\begin{array}{l}.014 \\
(.05)\end{array}$ & 8.81 & $\begin{array}{l}.103 \\
(.144)\end{array}$ & $\begin{array}{c}.089 \\
(0.560)\end{array}$ \\
\hline Observations & 4,849 & & 4,849 & & \\
\hline \multicolumn{6}{|l|}{ C. Female } \\
\hline Formally Employed & .178 & $\begin{array}{l}.008^{* *} \\
(.004)\end{array}$ & .266 & $\begin{array}{l}.026^{* *} \\
(.013)\end{array}$ & $\begin{array}{c}.018 \\
(0.148)\end{array}$ \\
\hline Daily Earnings & .779 & $\begin{array}{l}.069^{*} \\
(.037)\end{array}$ & 8.92 & $\begin{array}{l}-.072 \\
(.132)\end{array}$ & $\begin{array}{l}-.141 \\
(0.313)\end{array}$ \\
\hline Observations & 5,335 & & 5,335 & & \\
\hline
\end{tabular}

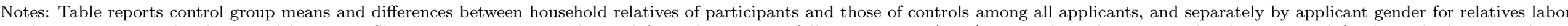

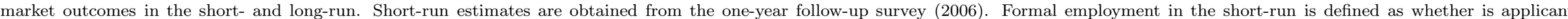

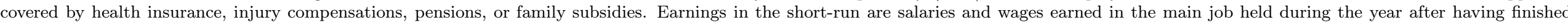

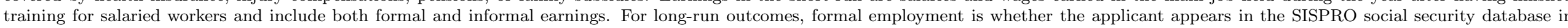

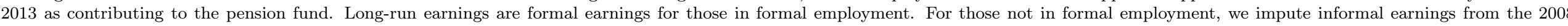

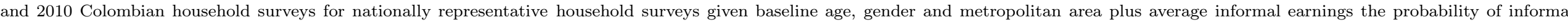

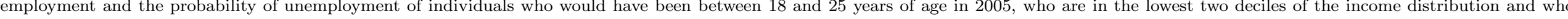

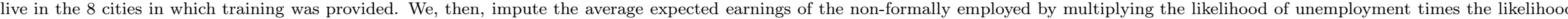

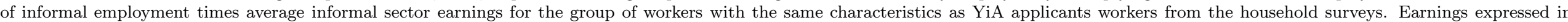

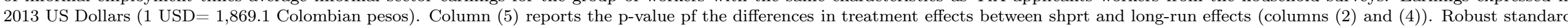
errors in parentheses. ${ }^{* * *} \mathrm{p}<0.01,{ }^{* *} \mathrm{p}<0.05,{ }^{*} \mathrm{p}<0.1$. 
Table 7: Test of Liquidity Constraints: Returns to Education using IVs for Direct + Indirect Costs

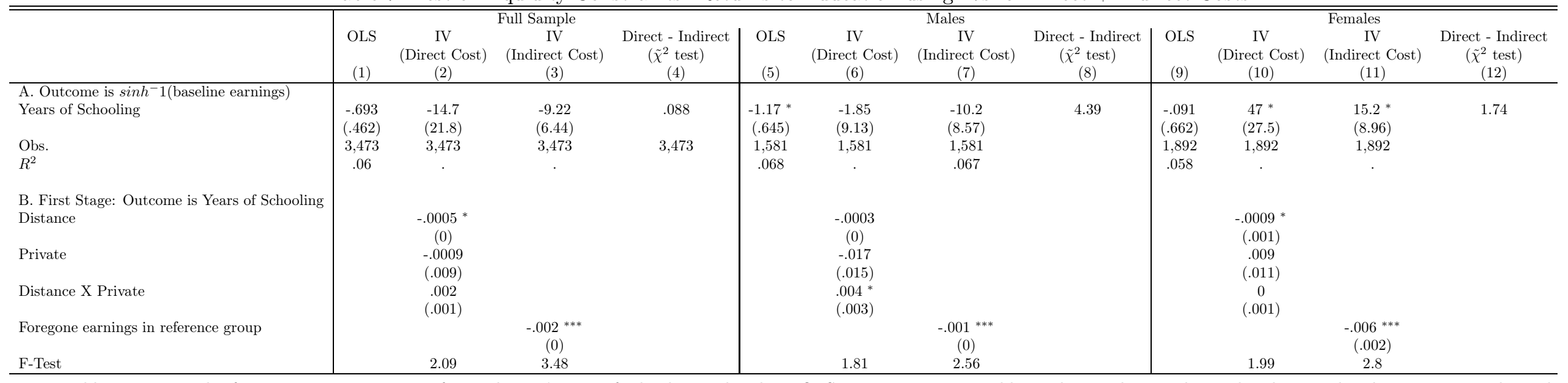

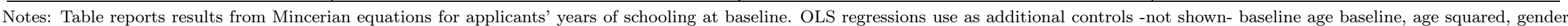

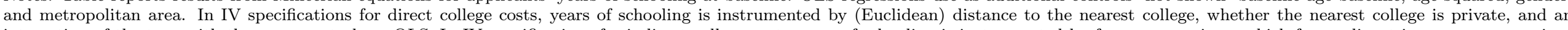

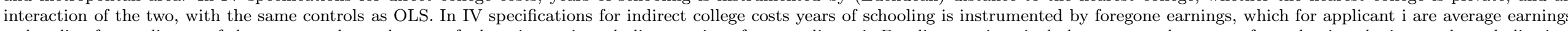

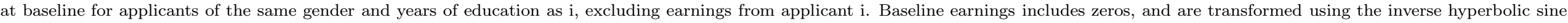

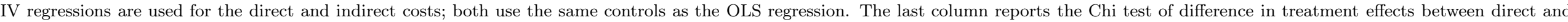
indirect cost. Robust standard errors in parentheses. ${ }^{* * *} \mathrm{p}<0.01,{ }^{* *} \mathrm{p}<0.05,{ }^{*} \mathrm{p}<0.1$ 
Table 8: Training Impacts on Applicants' Formal Education Outcomes, by Ex-Ante Returns to Education

\begin{tabular}{|c|c|c|c|c|c|c|c|c|c|c|}
\hline & \multicolumn{3}{|c|}{ All } & \multicolumn{3}{|c|}{ Males } & \multicolumn{3}{|c|}{ Females } & \multirow{3}{*}{$\begin{array}{c}\text { Male-Female } \\
\text { difference } \\
P-\text { value } \\
(10)\end{array}$} \\
\hline & \multirow{2}{*}{$\begin{array}{l}\text { Control } \\
\text { Mean } \\
(1)\end{array}$} & \multicolumn{2}{|c|}{ Participant } & \multirow{2}{*}{$\begin{array}{c}\text { Control } \\
\text { Mean } \\
(4)\end{array}$} & \multicolumn{2}{|c|}{ Participant } & \multirow{2}{*}{$\begin{array}{l}\text { Control } \\
\text { Mean } \\
(7) \\
\end{array}$} & \multicolumn{2}{|c|}{ Participant } & \\
\hline & & $\begin{array}{l}\text { Effect } \\
(2) \\
\end{array}$ & $\begin{array}{c}\text { Interaction } \\
(3) \\
\end{array}$ & & $\begin{array}{l}\text { Effect } \\
(5) \\
\end{array}$ & $\begin{array}{l}\text { Interaction } \\
\qquad(6) \\
\end{array}$ & & $\begin{array}{l}\text { Effect } \\
(8)\end{array}$ & $\begin{array}{c}\text { Interaction } \\
(9) \\
\end{array}$ & \\
\hline & & & & & All App & icants & & & & \\
\hline Completed secondary school after training & .061 & $\begin{array}{l}.098^{* *} \\
(.042)\end{array}$ & $\begin{array}{c}-.093^{* *} \\
(.044)\end{array}$ & .049 & $\begin{array}{c}.092 \\
(.057)\end{array}$ & $\begin{array}{l}-.091 \\
(.065)\end{array}$ & .071 & $\begin{array}{c}.076 \\
(.076)\end{array}$ & $\begin{array}{l}-.069 \\
(.074)\end{array}$ & 0.958 \\
\hline Tertiary Enrollment after YiA & .129 & $\begin{array}{c}.1 \\
(.062)\end{array}$ & $\begin{array}{l}-.073 \\
(.063)\end{array}$ & .146 & $\begin{array}{l}.195^{* *} \\
(.087)\end{array}$ & $\begin{array}{l}-.178^{*} \\
(.094)\end{array}$ & .115 & $\begin{array}{l}.008 \\
(.1)\end{array}$ & $\begin{array}{l}.024 \\
(.098)\end{array}$ & 0.066 \\
\hline Observations & 3,953 & & & 1,822 & & & 2,131 & & & \\
\hline
\end{tabular}

B. All Relatives

\begin{tabular}{|c|c|c|c|c|c|c|c|c|c|c|}
\hline Completed secondary school after training & .125 & $\begin{array}{c}.009 \\
(.031)\end{array}$ & $\begin{array}{c}.004 \\
(.032)\end{array}$ & .128 & $\begin{array}{c}.009 \\
(.044)\end{array}$ & $\begin{array}{c}.007 \\
(.048)\end{array}$ & .123 & $\begin{array}{c}.026 \\
(.051)\end{array}$ & $\begin{array}{c}-.01 \\
(.049)\end{array}$ & 0.369 \\
\hline Tertiary Enrollment after YiA & .086 & $\begin{array}{c}.035 \\
(.029)\end{array}$ & $\begin{array}{l}-.024 \\
(.029)\end{array}$ & .088 & $\begin{array}{c}.035 \\
(.043)\end{array}$ & $\begin{array}{l}-.011 \\
(.047)\end{array}$ & .083 & $\begin{array}{l}-.031 \\
(.043)\end{array}$ & $\begin{array}{c}.03 \\
(.041)\end{array}$ & 0.988 \\
\hline Observations & 15,247 & & & 6,828 & & & 8,419 & & & \\
\hline
\end{tabular}

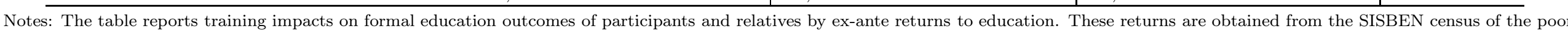

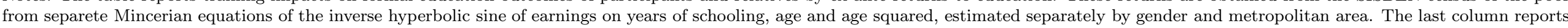

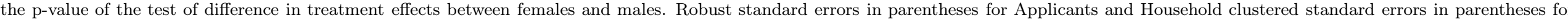
relatives. ${ }^{* * *} \mathrm{p}<0.01,{ }^{* *} \mathrm{p}<0.05,{ }^{*} \mathrm{p}<0.1$. 
Table 9: Impacts on Secondary School Exit Exam Scores of Applicants and Relatives

\begin{tabular}{|c|c|c|c|c|c|c|c|}
\hline & & $\overline{\text { All }}$ & \multicolumn{4}{|c|}{ Gender } & \multirow[b]{3}{*}{$\begin{array}{c}\text { Male-Female } \\
\text { difference } \\
P \text { - value } \\
(7) \\
\end{array}$} \\
\hline & & licants & \multicolumn{2}{|c|}{ Males } & \multicolumn{2}{|c|}{ Females } & \\
\hline & $\begin{array}{c}\text { Control } \\
\text { Mean } \\
(\mathrm{sd}) \\
(1)\end{array}$ & $\begin{array}{c}\text { Participant } \\
\text { Effect } \\
\text { (sd) } \\
(2)\end{array}$ & $\begin{array}{c}\text { Control } \\
\text { Mean } \\
(\mathrm{sd}) \\
(3)\end{array}$ & $\begin{array}{c}\text { Participant } \\
\text { Effect } \\
\text { (sd) } \\
(4)\end{array}$ & $\begin{array}{c}\text { Control } \\
\text { Mean } \\
(\mathrm{sd}) \\
(5)\end{array}$ & $\begin{array}{c}\text { Participant } \\
\text { Effect } \\
\text { (sd) } \\
(6)\end{array}$ & \\
\hline \multicolumn{8}{|l|}{ A. All Applicants } \\
\hline Secondary exit score after training & 42.7 & $\begin{array}{c}-7.55 \\
(6.9)\end{array}$ & & $\begin{array}{l}-8.37 \\
(10.7)\end{array}$ & 40.6 & $\begin{array}{c}-10.7 \\
(12)\end{array}$ & 0.923 \\
\hline Observations & 167 & & 72 & & 95 & & \\
\hline \multicolumn{8}{|l|}{ B. All Relatives } \\
\hline Secondary exit score after training & 43.7 & $\begin{array}{l}-1.86 \\
(3.47)\end{array}$ & 43.2 & $\begin{array}{l}-.341 \\
(5.83)\end{array}$ & 44.1 & $\begin{array}{c}1.81 \\
(5.32)\end{array}$ & 0.760 \\
\hline Secondary exit score after training (Male relative) & 37 & $\begin{array}{c}1.26 \\
(6.02)\end{array}$ & 35.8 & $\begin{array}{l}-2.19 \\
(13.9)\end{array}$ & 38.1 & $\begin{array}{c}-9.6 \\
(12.1)\end{array}$ & 0.193 \\
\hline Secondary exit score after training (Female relative) & 51 & $\begin{array}{l}-5.38 \\
(5.83)\end{array}$ & 53.1 & $\begin{array}{c}20.9 \\
(31.1)\end{array}$ & 49.7 & $\begin{array}{c}6.65 \\
(8.42)\end{array}$ & 0.188 \\
\hline Observations & 201 & & 84 & & 117 & & \\
\hline
\end{tabular}

Notes: Table reports training impacts on secondary school exit exam scores, measured in percentiles. Baseline controls -not shown in the table- include gender, age, married, , secondary completed before training, enrolled in tertiary before training, working according with the census of the poor salary, profit, formal employment, contract, tenure, days worked, hours worked and training institution fixed effects. The last column reports the p-value of the test of difference in treatment effects between females and males. Columns 2 , 5 and 8 report estimates from OLS regresions in the sample of applicants and relatives who took the SABER 11 test. Columns 3, 6 and 9 report estimates from Tobit models with a lower-level censoring point at the 25th percentile of the corresponding distribution. Observations which missing test scores or with scores below the 25th percentile are imputed at the 25 th percentile score, which is 21 points in the applicant sample and 18 points in the household relatives sample. ${ }^{* * *} \mathrm{p}<0.01,{ }^{* *} \mathrm{p}<0.05,{ }^{*} \mathrm{p}<0.1$. 
Table 10: Enrollment in Tertiary Education's Knowledge Domains by Vocational Field of Training (\%)

\begin{tabular}{|c|c|c|c|c|c|c|c|c|}
\hline \multirow[b]{2}{*}{ Training Field } & \multirow[b]{2}{*}{ Agricultural and Mining } & \multicolumn{5}{|c|}{ Tertiary Education Domain } & \multirow[b]{2}{*}{ Social Sciences } & \multirow[b]{2}{*}{ Total general } \\
\hline & & Arts & Economics, Business and related & Engineering & Health and Education & Natural Sciences and Math & & \\
\hline Full Sample & 10 & 4 & 30 & 40 & 3 & 4 & 16 & 100 \\
\hline Agricultural and Mining & 0 & 0 & 0 & 100 & 0 & 0 & 0 & 100 \\
\hline Arts & 0 & 0 & 33 & 33 & 33 & 0 & 0 & 100 \\
\hline Construction and Manufacture & 0 & 5 & 35 & 40 & 5 & 5 & 10 & 100 \\
\hline Health and Education & 0 & 0 & 20 & 20 & 40 & 0 & 20 & 100 \\
\hline Natural Science & 0 & 0 & 0 & 0 & 0 & 100 & 0 & 100 \\
\hline Social Sciences & 0 & 0 & 100 & 0 & 0 & 0 & 0 & 100 \\
\hline Art & 0 & 0 & 0 & 100 & 0 & 0 & 0 & 100 \\
\hline Business, Finance and Sales & 3 & 6 & 21 & 52 & 6 & 0 & 12 & 100 \\
\hline Construction and Manufacture & 0 & 9 & 27 & 64 & 0 & 0 & 0 & 100 \\
\hline Health & 0 & 0 & 0 & 25 & 50 & 0 & 25 & 100 \\
\hline Natural Science & 0 & 0 & 0 & 0 & 0 & 100 & 0 & 100 \\
\hline Social Sciences & 0 & 0 & 100 & 0 & 0 & 0 & 0 & 100 \\
\hline Females & 0 & 2 & 41 & 27 & 12 & 7 & 10 & 100 \\
\hline Agricultural and Mining & 0 & 0 & 0 & 100 & 0 & 0 & 0 & 100 \\
\hline Art & 0 & 0 & 50 & 0 & 50 & 0 & 0 & 100 \\
\hline Business, Finance and Sales & 0 & 4 & 41 & 33 & 11 & 4 & 7 & 100 \\
\hline Health & 0 & 0 & 100 & 0 & 0 & 0 & 0 & 100 \\
\hline Natural Science & 0 & 0 & 0 & 0 & 0 & 100 & 0 & 100 \\
\hline
\end{tabular}

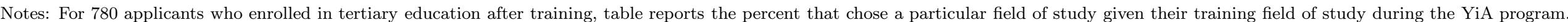


Table 11: Program Costs and Internal Rates of Return

\begin{tabular}{lcc}
\hline \hline & Female Applicants & Male Applicants \\
\hline
\end{tabular}

Panel A. Program Cost (Per participant)

Direct Program Cost USD

Marginal Cost of Public Funds USD

308

(40 cents/dollar)

Lost of Tenure Cost

64

Total Cost (Per participant)

Panel B. Internal Rates of Return

Direct Earnings Effect on Participants

0.221

0.102

Direct Effect + Education Spillover on Participants

0.235

0.205

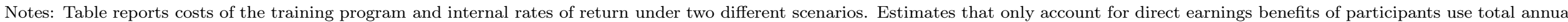

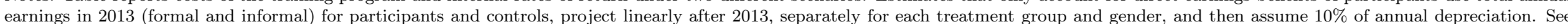

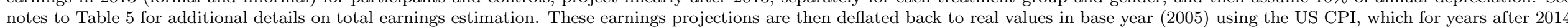

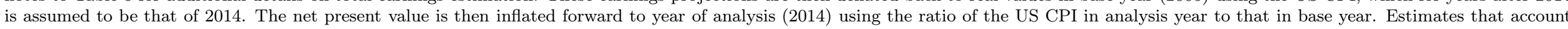

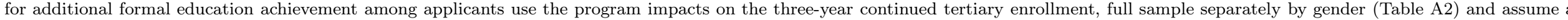
$10 \%$ annual return to an additional year of education. 
A Appendix 
Table A1: Training Impact on Educational Attainment of Applicants, Without Baseline Controls

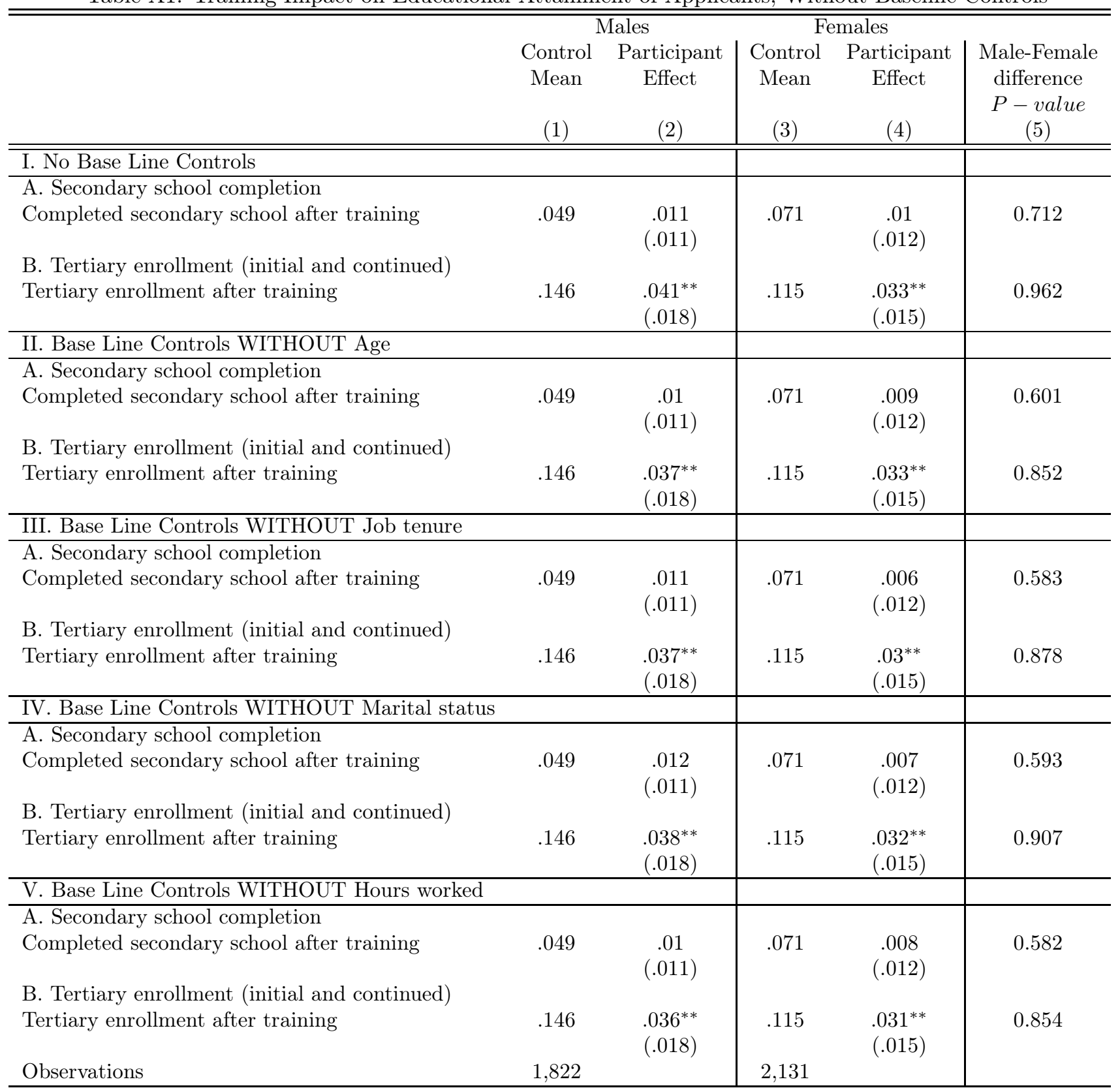

Notes: The table reports the difference in the probability of: completing secondary school (as measured by whether applicants take the SABER 11 test), and enrollment in tertiary education (prior -placebo test-, initial and continued) from SPADIES data between treatment and control groups. The baseline controls excluded from Panel I: are gender, age, married, secondary completed before training, enrolled in tertiary before training, working according with the census of the poor, salary, profit, formal employment, contract, tenure, days worked, hours worked; Panel II: Secondary completed before training, enrolled in tertiary before training; Panel III: Working according with the census of the poor; Panel IV: Marital Status. gender, age, married, secondary completed before training, enrolled in tertiary before training, working according with the census of the poor, salary, profit, formal employment, contract, tenure, days worked, hours worked and training institution fixed effects. The last column reports the p-value of the test of difference in treatment effects between women and men. Robust standard errors in parentheses. ${ }^{* * *} \mathrm{p}<0.01,{ }^{* *} \mathrm{p}<0.05,{ }^{*} \mathrm{p}<0.1$. 
Table A2: Training Impacts on Educational Attainment of Applicants with adjusted Q values.

\begin{tabular}{|c|c|c|c|c|c|c|c|c|c|}
\hline & \multirow[b]{2}{*}{$\begin{array}{c}\text { Control } \\
\text { Mean } \\
(1) \\
\end{array}$} & \multicolumn{3}{|c|}{ Males } & \multicolumn{4}{|c|}{ Females } & \multirow[b]{2}{*}{$\begin{array}{c}\text { Male-Female } \\
\text { difference } \\
P-\text { value } \\
(9)\end{array}$} \\
\hline & & $\begin{array}{c}\text { Participant } \\
\text { Effect } \\
(2) \\
\end{array}$ & $\begin{array}{c}\text { Naive } \\
P-\text { value } \\
(3)\end{array}$ & $\begin{array}{c}\text { FDR } \\
q_{- \text {value }} \\
(4) \\
\end{array}$ & $\begin{array}{c}\text { Control } \\
\text { Mean } \\
(5) \\
\end{array}$ & $\begin{array}{c}\text { Participant } \\
\text { Effect } \\
(6) \\
\end{array}$ & $\begin{array}{c}\text { Naive } \\
P-\text { value } \\
(7)\end{array}$ & $\begin{array}{c}\text { FDR } \\
q_{- \text {value }} \\
(8) \\
\end{array}$ & \\
\hline \multicolumn{10}{|l|}{ A. Secondary school completion } \\
\hline Completed secondary school after training & .049 & $\begin{array}{c}.01 \\
(.011)\end{array}$ & .357 & .218 & .071 & $\begin{array}{c}.007 \\
(.012)\end{array}$ & .535 & .365 & 0.585 \\
\hline \multicolumn{10}{|l|}{ B. Initial and continued Tertiary enrollment } \\
\hline Tertiary enrollment after training & .146 & $\begin{array}{c}.037 \\
(.018)\end{array}$ & .038 & .083 & .115 & $\begin{array}{c}.032 \\
(.015)\end{array}$ & .031 & .066 & 0.875 \\
\hline Observations & 1,822 & & & & 2,131 & & & & \\
\hline
\end{tabular}

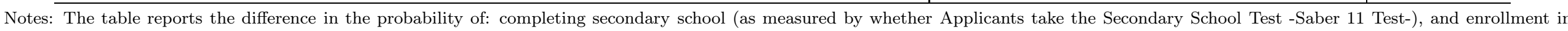

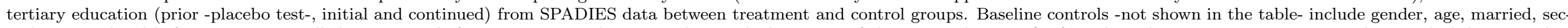

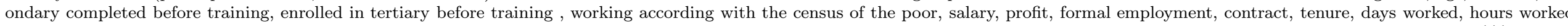

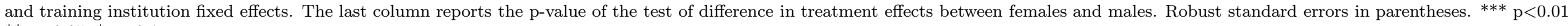
${ }^{* *} \mathrm{p}<0.05,{ }^{*} \mathrm{p}<0.1$. 
Table A3: Training Impact on Educational Attainment of Relatives, Without Baseline Controls

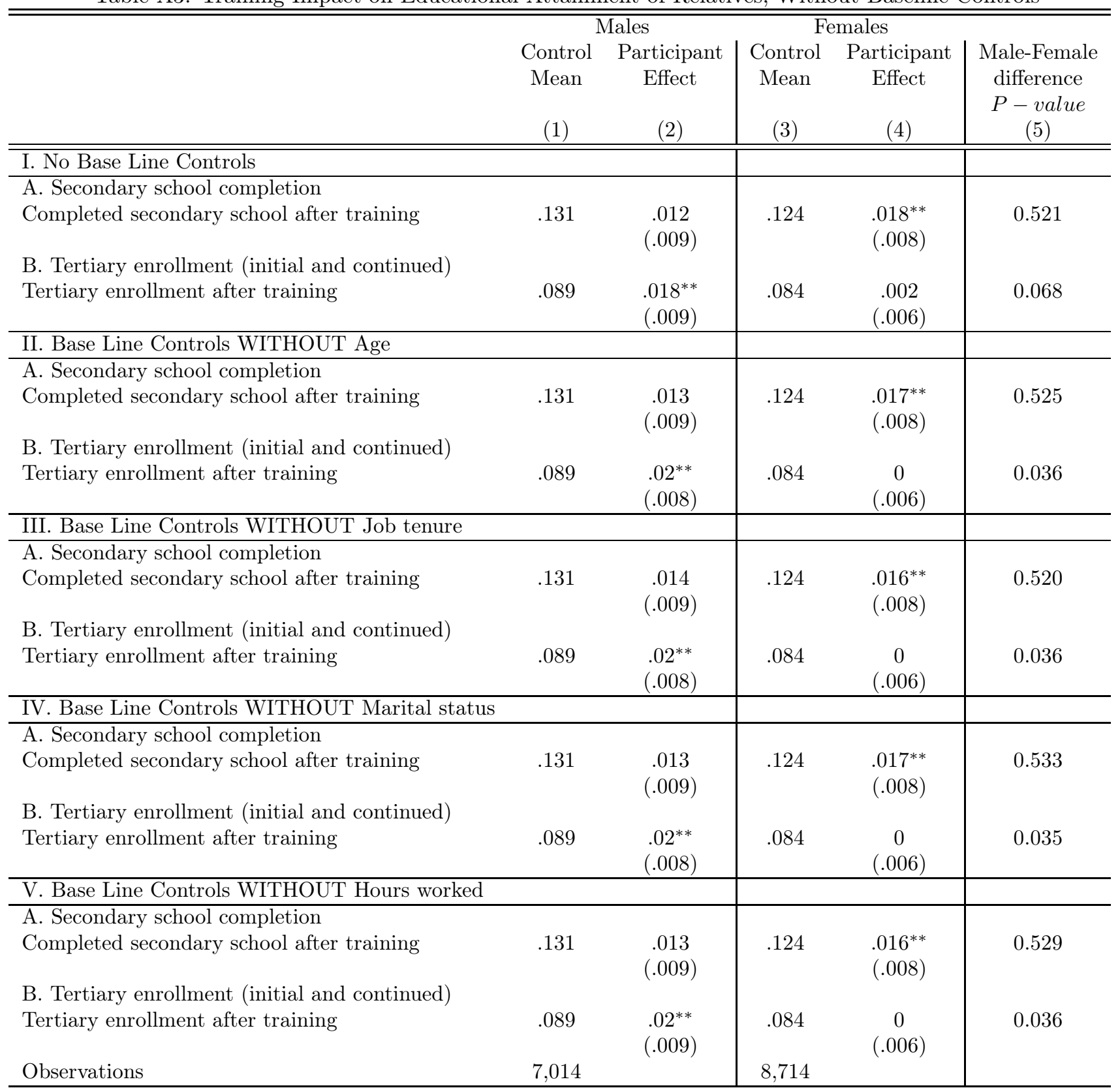

Notes: The table reports the difference in the probability of completing secondary school (as measured by whether applicants take the SABER 11 test) and of enrollment in tertiary education (initial and continued) from SPADIES data between treatment and control groups. The baseline controls excluded from Panel I: are gender, age, married, secondary completed before training, enrolled in tertiary before training, working according with the census of the poor, salary, profit, formal employment, contract, tenure, days worked, hours worked; Panel II: Secondary completed before training, enrolled in tertiary before training; Panel III: Working according with the census of the poor; Panel IV: Marital Status. gender, age, married, secondary completed before training, enrolled in tertiary before training, working according with the census of the poor, salary, profit, formal employment, contract, tenure, days worked, hours worked and training institution fixed effects. The last column reports the p-value of the test of difference in treatment effects between women and men. Household clustered standard errors in parentheses. ${ }^{* * *} \mathrm{p}<0.01,{ }^{* *} \mathrm{p}<0.05,{ }^{*} \mathrm{p}<0.1$. 
Table A4: Training Impacts on Educational Attainment of Relatives with adjusted Q values.

\begin{tabular}{|c|c|c|c|c|c|c|c|c|c|}
\hline & \multicolumn{4}{|c|}{ Males } & \multicolumn{4}{|c|}{ Females } & \multirow[b]{2}{*}{$\begin{array}{c}\text { Male-Female } \\
\text { difference } \\
P-\text { value } \\
(9) \\
\end{array}$} \\
\hline & $\begin{array}{c}\text { Control } \\
\text { Mean } \\
(1) \\
\end{array}$ & $\begin{array}{c}\text { Participant } \\
\text { Effect } \\
(2) \\
\end{array}$ & $\begin{array}{c}\text { Naive } \\
P-\text { value } \\
(3)\end{array}$ & $\begin{array}{c}\text { FDR } \\
q_{- \text {value }} \\
(4) \\
\end{array}$ & $\begin{array}{c}\text { Control } \\
\text { Mean } \\
(5) \\
\end{array}$ & $\begin{array}{c}\text { Participant } \\
\text { Effect } \\
(6) \\
\end{array}$ & $\begin{array}{c}\text { Naive } \\
P-\text { value } \\
(7)\end{array}$ & $\begin{array}{c}\text { FDR } \\
q_{- \text {value }} \\
(8) \\
\end{array}$ & \\
\hline \multicolumn{10}{|l|}{ A. Secondary school completion } \\
\hline Completed secondary school after training & .131 & $\begin{array}{c}.013 \\
(.009)\end{array}$ & .16 & .087 & .124 & $\begin{array}{c}.017 \\
(.008)\end{array}$ & .036 & .078 & 0.527 \\
\hline Completed secondary school after training (Male relative) & .133 & $\begin{array}{c}0 \\
(.012)\end{array}$ & .985 & 1 & .136 & $\begin{array}{c}.007 \\
(.012)\end{array}$ & .522 & 1 & 0.671 \\
\hline Completed secondary school after training (Female relative) & .128 & $\begin{array}{l}.025 \\
(.013)\end{array}$ & .062 & .086 & .115 & $\begin{array}{l}.024 \\
(.01)\end{array}$ & .021 & .086 & 0.771 \\
\hline \multicolumn{10}{|l|}{ B. Initial and continued Tertiary enrollment } \\
\hline Tertiary enrollment after training & .089 & $\begin{array}{c}.02 \\
(.008)\end{array}$ & .019 & .041 & .084 & $\begin{array}{c}0 \\
(.006)\end{array}$ & .948 & .902 & 0.037 \\
\hline Tertiary enrollment after training (Male relative) & .085 & $\begin{array}{l}.014 \\
(.01)\end{array}$ & .161 & 1 & .086 & $\begin{array}{l}-.006 \\
(.009)\end{array}$ & .511 & 1 & 0.101 \\
\hline Tertiary enrollment after training (Female relative) & .094 & $\begin{array}{c}.025 \\
(.012)\end{array}$ & .039 & .086 & .083 & $\begin{array}{c}.002 \\
(.009)\end{array}$ & .815 & .256 & 0.125 \\
\hline Observations & 1,325 & & & & 1,681 & & & & \\
\hline
\end{tabular}

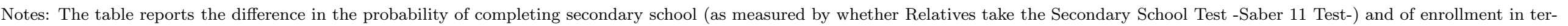

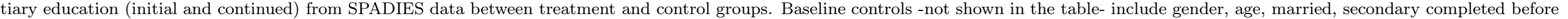

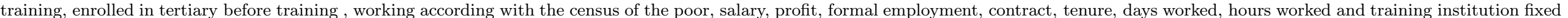

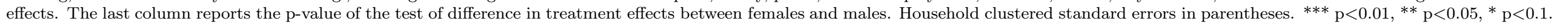


Table A5: Difference Between Short- And Long-Term Labor Market Impacts of Training (Applicants) with adjusted Q values.

\begin{tabular}{|c|c|c|c|c|c|c|c|c|c|}
\hline & \multirow[b]{2}{*}{$\begin{array}{c}\text { Control } \\
\text { Mean } \\
(1) \\
\end{array}$} & \multicolumn{3}{|c|}{ Short Run } & \multirow[b]{2}{*}{$\begin{array}{l}\text { Control } \\
\text { Mean } \\
(5) \\
\end{array}$} & \multicolumn{2}{|c|}{$\begin{array}{ll}\text { Long Run } \\
\end{array}$} & \multirow[b]{2}{*}{$\begin{array}{c}\mathrm{FDR} \\
q_{- \text {value }} \\
(8) \\
\end{array}$} & \multirow[b]{2}{*}{$\begin{array}{c}\text { Short - Long } \\
\text { run difference } \\
(9)\end{array}$} \\
\hline & & $\begin{array}{c}\text { Participant } \\
\text { Effect } \\
(2) \\
\end{array}$ & $\begin{array}{c}\text { Naive } \\
p_{- \text {value }} \\
(3)\end{array}$ & $\begin{array}{c}\text { FDR } \\
q_{- \text {-value }} \\
(4)\end{array}$ & & $\begin{array}{c}\text { Participant } \\
\text { Effect } \\
(6) \\
\end{array}$ & $\begin{array}{c}\text { Naive } \\
p_{- \text {value }} \\
(7)\end{array}$ & & \\
\hline \multicolumn{10}{|l|}{ A.Male } \\
\hline Formally Employed & .245 & $\begin{array}{c}.078 \\
(.023)\end{array}$ & .001 & .001 & .781 & $\begin{array}{l}.045 \\
(.02)\end{array}$ & .026 & .018 & 0.277 \\
\hline Daily Earnings & $\begin{array}{r}2.35 \\
1,682\end{array}$ & $\begin{array}{c}1.13 \\
(.254)\end{array}$ & 0 & .001 & $\begin{array}{r}10.6 \\
1,682\end{array}$ & $\begin{array}{l}.195 \\
(.147)\end{array}$ & .186 & .049 & 0.001 \\
\hline \multicolumn{10}{|l|}{ B. Female } \\
\hline Formally Employed & .145 & $\begin{array}{c}.064 \\
(.017)\end{array}$ & 0 & .001 & .575 & $\begin{array}{c}.07 \\
(.021)\end{array}$ & .001 & .001 & 0.820 \\
\hline Daily Earnings & 1.37 & $\begin{array}{l}.658 \\
(.17)\end{array}$ & 0 & .001 & 7.71 & $\begin{array}{c}.264 \\
(.121)\end{array}$ & .029 & .008 & 0.059 \\
\hline Observations & 2,117 & & & & 2,117 & & & & \\
\hline
\end{tabular}

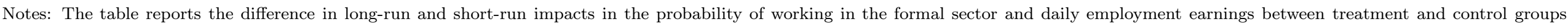

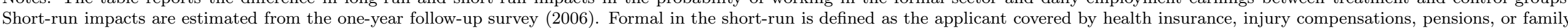

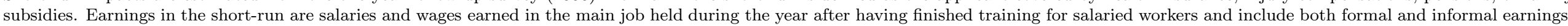

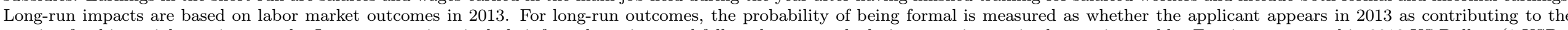

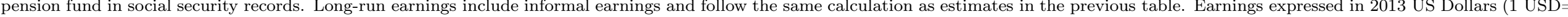

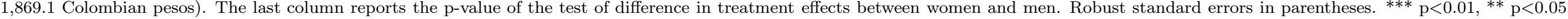
$* \mathrm{p}<0.1$. 
Table A6: Summary Statistics of Distance to College from Applicant's Residence at Baseline (in Kilometers)

\begin{tabular}{|c|c|c|c|c|}
\hline & \multirow{3}{*}{$\begin{array}{c}\text { All } \\
\text { Applicants } \\
\text { Mean } \\
(1)\end{array}$} & \multicolumn{2}{|c|}{ Gender } & \multirow{3}{*}{$\begin{array}{c}\text { Male-Female } \\
P-\text { value } \\
\text { (4) }\end{array}$} \\
\hline & & Males & Females & \\
\hline & & $\begin{array}{l}\text { Mean } \\
(2)\end{array}$ & $\begin{array}{c}\text { Mean } \\
(3)\end{array}$ & \\
\hline To actual college in which applicant enrolled & 10 & 8.52 & 11.6 & 0.002 \\
\hline To closest college & 2.83 & 3.06 & 2.58 & 0.771 \\
\hline To closest private college & 2.56 & 2.71 & 2.46 & 0.421 \\
\hline To closest public college & 3.1 & 3.29 & 2.78 & 0.741 \\
\hline Median distance to college & 11 & 11.1 & 10.8 & 0.953 \\
\hline Average distance to college & 16.6 & 16.8 & 16.3 & 0.644 \\
\hline To farthest college college & 69.5 & 67.8 & 71.4 & 0.178 \\
\hline Observations & 536 & 279 & 257 & \\
\hline
\end{tabular}

Notes: Table shows the distribution of route distances (in Kilometers) between applicants' address at baseline and various colleges in the same department (state) in which the applicant resides at baseline. Robust standard errors in parentheses. 
Table A7: Training and Secondary School Test Score Impacts on Educational Attainment

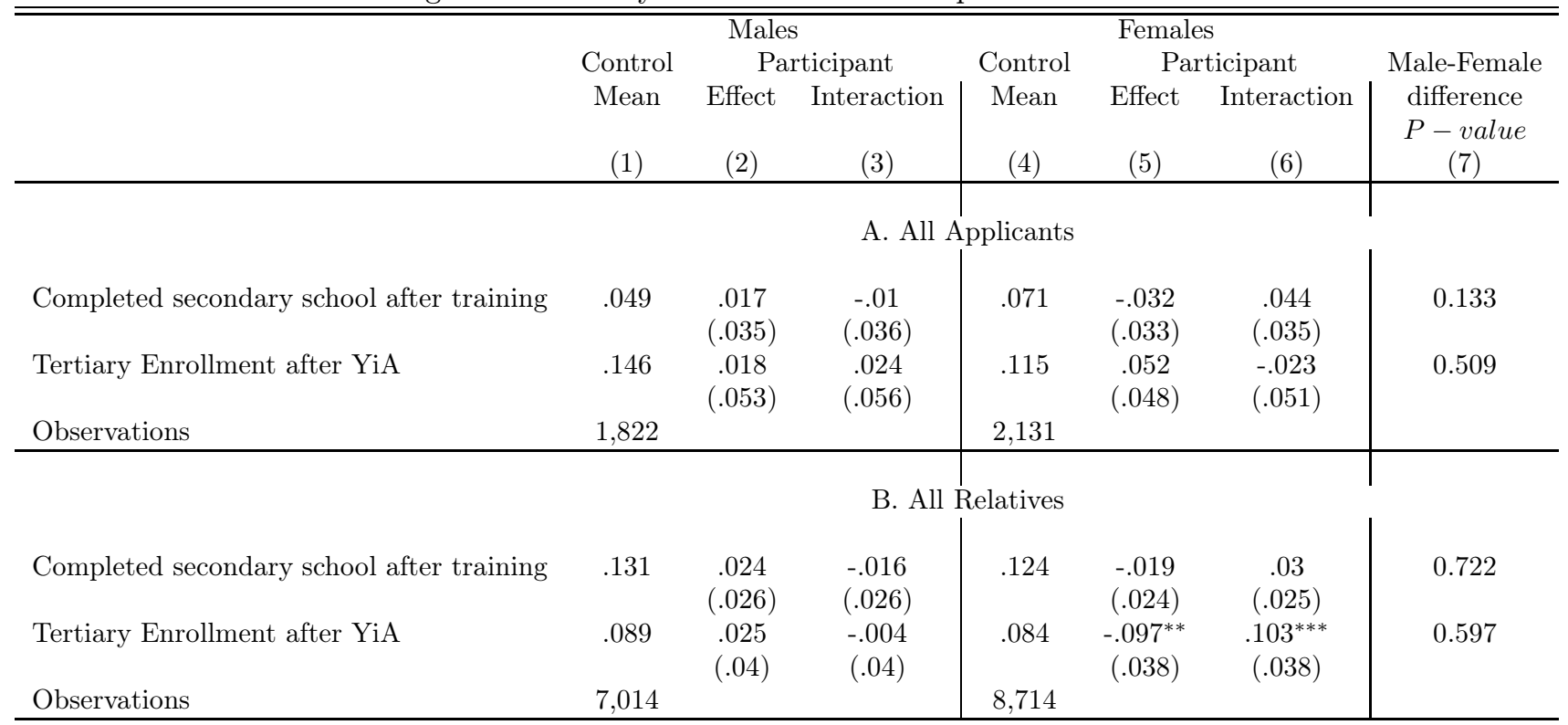

Notes: The table reports the difference in the probability of completing secondary school (as measured by whether Relatives take the Secondary School Test -Saber 11 Test-) and of enrollment in tertiary education (initial and continued) from SPADIES data between treatment and control groups. The interaction is between Training Impact and a Dummy that takes the value of 1 if the score is above the mean by gender. Baseline controls -not shown in the table- include gender, age, married, secondary completed before training, enrolled in tertiary before training, working according with the census of the poor, salary, profit, formal employment, contract, tenure, days worked, hours worked and training institution fixed effects. The last column reports the p-value of the test of difference in treatment effects between females and males. Robust standard errors for applicants and household clustered standard errors for relatives in parentheses. ${ }^{* * *} \mathrm{p}<0.01,{ }^{* *} \mathrm{p}<0.05,{ }^{*} \mathrm{p}<0.1$. 
Table A8: Differential Training Impact on Educational Attainment for Those with Earnings above the Mean by Gender two years after YiA

\begin{tabular}{|c|c|c|c|c|c|c|c|}
\hline & \multicolumn{3}{|c|}{ Males } & \multicolumn{3}{|c|}{ Females } & \multirow{4}{*}{$\begin{array}{c}\text { Male-Female } \\
\text { difference } \\
P-\text { value } \\
(7)\end{array}$} \\
\hline & \multirow{3}{*}{$\begin{array}{c}\text { Control } \\
\text { Mean } \\
(1) \\
\end{array}$} & \multicolumn{2}{|c|}{ Participant } & \multirow{3}{*}{$\begin{array}{c}\text { Control } \\
\text { Mean } \\
(4) \\
\end{array}$} & \multicolumn{2}{|c|}{ Participant } & \\
\hline & & Effect & Interaction & & Effect & Interaction & \\
\hline & & $(2)$ & $(3)$ & & $(5)$ & $(6)$ & \\
\hline & \multicolumn{6}{|c|}{ A. All Applicants } & \multirow{5}{*}{0.241} \\
\hline Completed secondary school after training & .049 & $\begin{array}{l}.023 \\
(017)\end{array}$ & $\begin{array}{l}-.02 \\
(022)\end{array}$ & .071 & $\begin{array}{c}.01 \\
(015)\end{array}$ & $\begin{array}{l}-.008 \\
(024)\end{array}$ & \\
\hline Tertiary Enrollment after YiA & .146 & .025 & .018 & .115 & .026 & .008 & \\
\hline & & $(.023)$ & $(.035)$ & & $(.017)$ & $(.031)$ & \\
\hline \multirow[t]{2}{*}{ Observations } & 1,822 & & & 2,131 & & & \\
\hline & \multicolumn{6}{|c|}{ B. All Relatives } & \multirow[b]{2}{*}{0.874} \\
\hline Completed secondary school after training & .131 & $\begin{array}{l}.013 \\
(01)\end{array}$ & $\begin{array}{l}.007 \\
(019)\end{array}$ & .124 & $\begin{array}{l}.019^{* *} \\
(009)\end{array}$ & -.018 & \\
\hline Tertiary Enrollment after YiA & .089 & $.021^{* *}$ & .003 & .084 & .002 & $\begin{array}{l}.011 \\
-.01\end{array}$ & 0.462 \\
\hline & & $(.009)$ & $(.022)$ & & $(.007)$ & $(.018)$ & \\
\hline Observations & 7,014 & & & 8,714 & & & \\
\hline
\end{tabular}

Notes: The table reports the difference in the probability of completing secondary school (as measured by whether Relatives take the Secondary School Test -Saber 11 Test-) and of enrollment in tertiary education (initial and continued) from SPADIES data between treatment and control groups. The interaction is between Trainig Impact and a Dummy that takes the value of 1 if the Income in PILA two years after YiA is above the mean by gender, age, married, secondary completed before training, enrolled in tertiary before training, working according with the census of the poor, salary, profit, formal employment, contract, tenure, days worked, hours worked and training institution fixed effects. The last column reports the p-value of the test of difference in treatment effects between females and males. Robust standard errors for applicants, and household clustered standard errors for relatives in parentheses. ${ }^{* * *} \mathrm{p}<0.01,{ }^{* *}$ $\mathrm{p}<0.05, * \mathrm{p}<0.1$. 
Table A9: Training impact on Higher Education Enrollment

\begin{tabular}{|c|c|c|c|c|c|c|c|}
\hline & \multicolumn{2}{|c|}{ All Applicants } & \multicolumn{2}{|c|}{ Males } & \multicolumn{2}{|c|}{ Females } & \multirow{2}{*}{$\begin{array}{c}P-\text { value } \\
\text { Male-Female } \\
\text { difference } \\
(7) \\
\end{array}$} \\
\hline & $\begin{array}{l}\text { Control } \\
\text { Mean } \\
(1)\end{array}$ & $\begin{array}{c}\text { Participant } \\
\text { Effect } \\
(2)\end{array}$ & $\begin{array}{l}\text { Control } \\
\text { Mean } \\
(3)\end{array}$ & $\begin{array}{c}\text { Participant } \\
\text { Effect } \\
(4)\end{array}$ & $\begin{array}{l}\text { Control } \\
\text { Mean } \\
(5)\end{array}$ & $\begin{array}{c}\text { Participant } \\
\text { Effect } \\
(6)\end{array}$ & \\
\hline \multicolumn{8}{|l|}{ A. All Applicants } \\
\hline Enrolled in vocational college & .02 & $\begin{array}{c}.008 \\
(.005)\end{array}$ & .022 & $\begin{array}{c}.01 \\
(.009)\end{array}$ & .019 & $\begin{array}{c}.004 \\
(.007)\end{array}$ & 0.733 \\
\hline Enrolled in private vocational college & .013 & $\begin{array}{c}.006 \\
(.004)\end{array}$ & .01 & $\begin{array}{c}.013^{*} \\
(.006)\end{array}$ & .015 & $\begin{array}{c}0 \\
(.006)\end{array}$ & 0.206 \\
\hline Enrolled in private university & .06 & $\begin{array}{c}.025^{* * *} \\
(.009)\end{array}$ & .052 & $\begin{array}{l}.044^{* * *} \\
(.014)\end{array}$ & .065 & $\begin{array}{c}.014 \\
(.012)\end{array}$ & 0.117 \\
\hline Enrolled in public university & .079 & $\begin{array}{l}-.005 \\
(.009)\end{array}$ & .101 & $\begin{array}{l}-.014 \\
(.015)\end{array}$ & .061 & $\begin{array}{c}.007 \\
(.011)\end{array}$ & 0.229 \\
\hline Observations & 3,583 & & 1,651 & & 1,932 & & \\
\hline \multicolumn{8}{|l|}{ B. All Relatives } \\
\hline Enrolled in vocational college & .012 & $\begin{array}{c}0 \\
(.002)\end{array}$ & .01 & $\begin{array}{c}.002 \\
(.003)\end{array}$ & .014 & $\begin{array}{l}-.002 \\
(.003)\end{array}$ & 0.236 \\
\hline Enrolled in private vocational college & .009 & $\begin{array}{l}-.001 \\
(.002)\end{array}$ & .006 & $\begin{array}{l}.001 \\
(.002)\end{array}$ & .011 & $\begin{array}{l}-.004 \\
(.002)\end{array}$ & 0.170 \\
\hline Enrolled in private university & .039 & $\begin{array}{l}.004 \\
(.004)\end{array}$ & .04 & $\begin{array}{l}.008 \\
(.006)\end{array}$ & .037 & $\begin{array}{c}.001 \\
(.005)\end{array}$ & 0.415 \\
\hline Enrolled in public university & .043 & $\begin{array}{l}.006 \\
(.004)\end{array}$ & .047 & $\begin{array}{c}.011 \\
(.007)\end{array}$ & .039 & $\begin{array}{c}.002 \\
(.006)\end{array}$ & 0.198 \\
\hline Observations & 10,195 & & 4,853 & & 5,342 & & \\
\hline
\end{tabular}

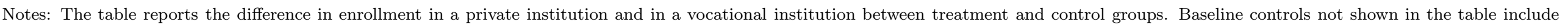

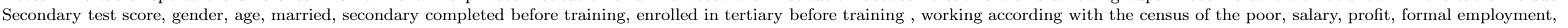

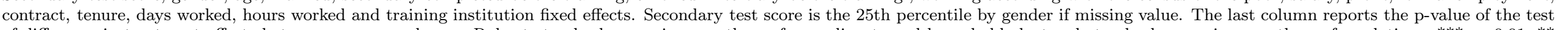

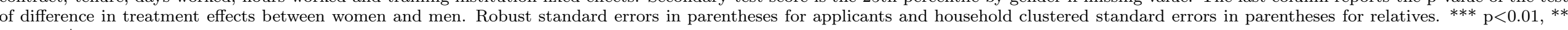
$\mathrm{p}<0.05,{ }^{*} \mathrm{p}<0.1$. 
Table A10: Initial and Continued Tertiary Education Enrollment (Applicants)

\begin{tabular}{|c|c|c|c|c|c|}
\hline & \multicolumn{2}{|c|}{ Males } & \multicolumn{2}{|c|}{ Females } & \multirow[b]{2}{*}{$\begin{array}{c}\text { Male-Female } \\
\text { difference } \\
P_{- \text {value }} \\
(5)\end{array}$} \\
\hline & $\begin{array}{c}\text { Control } \\
\text { Mean } \\
(1)\end{array}$ & $\begin{array}{l}\text { Participant } \\
\text { Effect } \\
(2) \\
\end{array}$ & $\begin{array}{c}\text { Control } \\
\text { Mean } \\
(3)\end{array}$ & $\begin{array}{l}\text { Participant } \\
\text { Effect } \\
(4) \\
\end{array}$ & \\
\hline \multicolumn{6}{|l|}{ A. All Applicants } \\
\hline One year after training & .136 & $\begin{array}{l}.04^{* *} \\
(.018)\end{array}$ & .113 & $\begin{array}{l}.031^{* *} \\
(.015)\end{array}$ & 0.987 \\
\hline Three years after training & .11 & $\begin{array}{l}.037^{* *} \\
(.016)\end{array}$ & .102 & $\begin{array}{l}.027^{*} \\
(.014)\end{array}$ & 0.974 \\
\hline Six years after training & .08 & $\begin{array}{c}.02 \\
(.014)\end{array}$ & .075 & $\begin{array}{c}.016 \\
(.012)\end{array}$ & 0.811 \\
\hline Nine year after training & .04 & $\begin{array}{l}.006 \\
(.01)\end{array}$ & .048 & $\begin{array}{l}.004 \\
(.01)\end{array}$ & 0.748 \\
\hline Observations & 1,822 & & 2,131 & & \\
\hline
\end{tabular}

Notes: The table reports the difference in initial tertiary education enrollment by year since participation in YiA between treatment and control groups. Baseline controls not shown in the table include gender, age, married, secondary completed before training, enrolled in tertiary before training, working according with the census of the poor, salary, profit, formal employment, contract, tenure, days worked, hours worked and training institution fixed effects The last column reports the p-value of the test of difference in treatment effects between women and men. Robust standard errors in parentheses for applicants and household clustered standard errors in parentheses for relatives. ${ }^{* * *} \mathrm{p}<0.01,{ }^{* *} \mathrm{p}<0.05,{ }^{*} \mathrm{p}<0.1$. 
Figure A1: Projected Annual Earnings of YiA Applicants

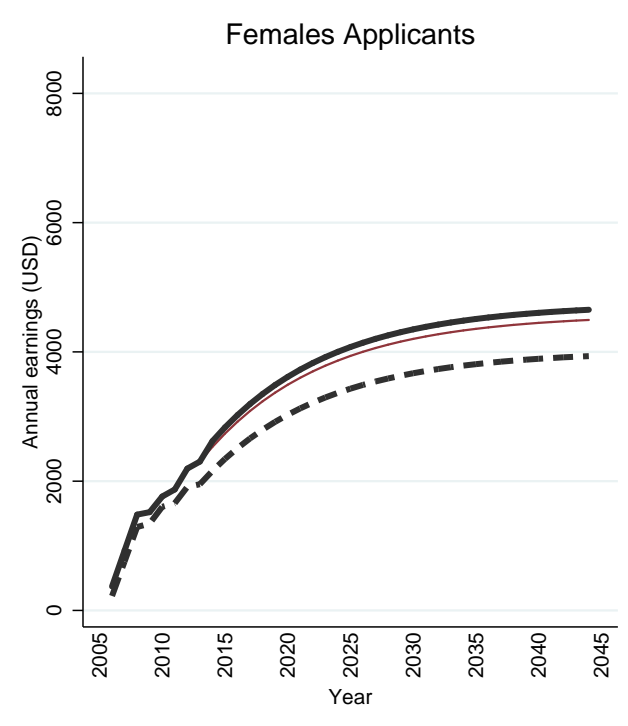

- - Female Losers

_ Female Winners, No Education Spillover

_ Female Winners, with Education Spillover

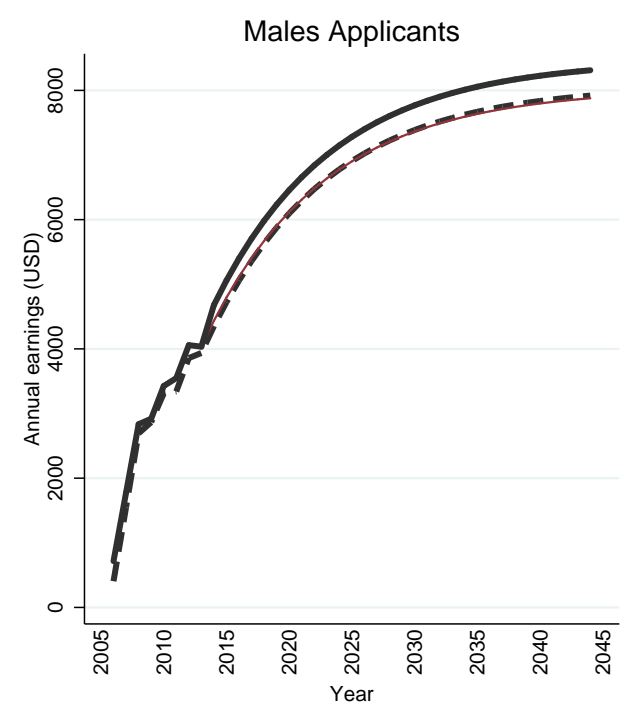

\section{- - Male Losers}

- Male Winners, No Education Spillover

Male Winners, with Education Spillover

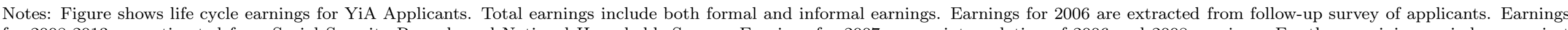

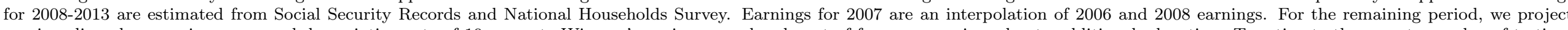

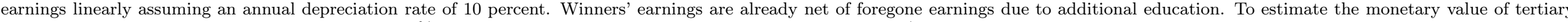

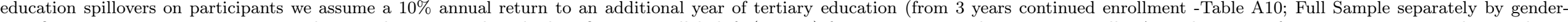

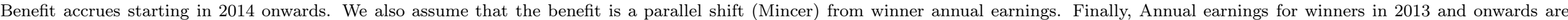
therefore, $E($ Withedreturn $)=E(w /$ oedreturn $)\left(1+\operatorname{Prob}(3 y r r e t e n t i o n) *(1+0.1)^{3}\right)$. 